\title{
Lexis
}

Journal in English Lexicology

$3 \mid 2009$

Borrowing

\section{Lexical Borrowing in Malaysian English: Influences of Malay}

Siew Imm Tan

\section{(2) OpenEdition}

Journals

\section{Electronic version}

URL: http://journals.openedition.org/lexis/629

DOI: $10.4000 /$ lexis. 629

ISSN: 1951-6215

\section{Publisher}

Université Jean Moulin - Lyon 3

\section{Electronic reference}

Siew Imm Tan, «Lexical Borrowing in Malaysian English: Influences of Malay », Lexis [Online], 3 | 2009,

Online since 27 July 2009, connection on 19 April 2019. URL : http://journals.openedition.org/

lexis/629; DOl : 10.4000/lexis.629

\section{(@) $\Theta \Theta$}

Lexis is licensed under a Creative Commons Attribution-NonCommercial-NoDerivatives 4.0

International License. 


\title{
Lexical Borrowing in Malaysian English: Influences of Malay ${ }^{1}$
}

Tan Siew $\mathrm{Imm}^{2}$

\begin{abstract}
During its evolution in the region that is today Malaysia, English has come into contact with a range of diverse, typologically-distinct languages. All these languages have influenced the lexicon of Malaysia English (ME), but it is Malay that has contributed to some of the most remarkable characteristics of this variety of English (see, for example, Lowenberg [1986 and 2000]; and Morais [2001]). This paper explores how the English-Malay contact has resulted in the incorporation of Malay features into the lexicon of ME. Using a corpus-based approach, the study analysed a comprehensive range of borrowed features extracted from the author's Malaysian English Newspaper Corpus (MEN Corpus) for the linguistic processes behind the borrowing phenomenon. Haugen's [1950] groundbreaking work on lexical borrowing provides the theoretical framework of this study. It is proposed that the underlying systematicity of the processes involved is reflected in the linguistic outcomes, and that there is much potential for corpus-based lexicography where ME is concerned. To highlight the nonarbitrariness of the borrowing phenomenon, the social and linguistic factors that motivate $\mathrm{ME}$ users to incorporate Malay lexical features into their variety of English are examined.
\end{abstract}

Keywords: language contact - new Englishes - lexical borrowing - loanwords - compound blends - loan translations - corpus-based lexicography

\footnotetext{
${ }^{1}$ This paper is based on a part of my PhD research, which was completed at the University of Hong Kong's School of English.

2 Assistant Professor, National Institute of Education, 1 Nanyang Walk, Singapore 637616. Comments and queries can be emailed to the author at: siewimm.tan@nie.edu.sg
} 


\section{Introduction}

Contact between the English and Malay languages in the region that is today Malaysia has a fascinating historical background that spans a period of more than 200 years (see Tan [2006: 4-12] for details). From the establishment of the British trading port in Penang in 1786 to the early interactions between Malay-speaking ${ }^{3}$ and English-speaking traders, and from the politically-charged relationships between the British colonial officers and the Malay ruling class in the $19^{\text {th }}$ century to the present-day communications among different groups of English-speaking and Malay-speaking bilinguals in Malaysia, the contact between the two languages has been intense and continuing.

The influences of the Malay language contribute to some of the most remarkable characteristics of Malaysian English (henceforth ME) today as these features distinguish this variety of English from, not only native varieties, but also other Asian varieties such as Philippine English, Hong Kong English, Indian English and, to a lesser degree, Singapore English. "The overriding influence of Malay" (Morais [2001: 35]) has been the focus of many inquiries into ME (see, in particular, Lowenberg [1986 and 2000]). The presence of features borrowed from Malay as well as the ancestral languages of the local Chinese and Indian communities is popularly interpreted as the outcome of linguistic acculturation, a process "by which English is equipped to function effectively in non-Western, multilingual speech communities" (Lowenberg [1986: 72]). Although influential, these studies (Lowenberg [1984, 1986 and 1992]; and Baskaran [1988]) have disregarded some of the more pertinent processes behind the phenomenon whereby borrowed features are incorporated into ME.

This paper goes beyond linguistic acculturation; rather it describes the linguistic processes behind the borrowing phenomenon, in other words, the mechanisms that ME users adopt, intentionally or subconsciously, in their efforts to improve the communicative and expressive functions of ME. More crucially, the study exploits a corpus-based approach in order to draw attention to the regularity and stability of these processes. It is proposed that the underlying systematicity of the processes involved is reflected in the linguistic outcomes, and that there is much potential for corpus-based lexicography where ME is concerned. To highlight the nonarbitrariness of the borrowing phenomenon, the social and linguistic factors that drive $\mathrm{ME}$ users to incorporate Malay lexical features into their variety of English are examined.

Haugen's [1950] groundbreaking work on lexical borrowing is used as a framework for analysing the diverse processes behind the adoption of Malay words and phrases in ME. The source of these features is the Malaysian English Newspaper Corpus (or the MEN Corpus), ${ }^{4}$ a 5-million word corpus of newspaper articles published in the two most authoritative Englishlanguage dailies in Malaysia - The STAR and the New Straits Times - over a six-month period from August 2001 to January 2002.

\section{Lexical borrowing in the context of new Englishes}

In the context of ME, and indeed of most varieties of English that have emerged in former British colonies, the interpretation of lexical borrowing must be premised on the understanding that borrowing does not have to be, and is in fact often not, initiated by native

\footnotetext{
${ }^{3}$ The Malay-speaking communities in and around the Malay Peninsula comprised not only the Malays but also the Arabs, Persians, Chinese, Tamils, Bengalis, Thais and so on. Because Malay was the lingua franca for trade in maritime Southeast Asia (see Reid [1988: 7]), traders needed to have, either themselves or through an interpreter, a working knowledge of the language.

${ }^{4}$ I compiled the Malaysian English Newspaper Corpus during the initial period of my PhD candidacy at the University of Hong Kong.
} 
speakers of English. This is in direct contradiction with the commonly-held perception that only native speakers of the recipient language can be agents of borrowing (see Thomason and Kaufman [1988: 37], and Winford [2003: 11]).

It cannot be denied that, as suggested by Schneider [2003a: 244-247], the early Englishspeaking settlers - traders and colonial officers from different regional backgrounds - played an important role in introducing some of the earliest borrowings from the languages spoken locally into their English language. In the case of ME, many of these features - toponyms, flora and fauna, especially - continue to be used today. However, with the departure of the colonial power and as the language they left behind became more widespread within the local community, borrowing was often undertaken by those within the community who speak English concurrently with other languages - persons who are bilingual or multilingual in English.

This observation is consistent with Thomason's revised view [2001: 68] that "borrowers do not have to be native speakers," and that fluent speakers are as capable as native speakers of engaging in lexical borrowing. Fluency is crucial because one needs to be reasonably familiar with the linguistic structure of a language to be able to introduce novel features into it without disrupting the original system of the language. Features that are introduced into the recipient language may then be transmitted to other members of the community. Features that are sustainable - that are particularly relevant to the needs of the community, for example may go on to become permanent additions to the vocabulary of other speakers of the recipient language, whether or not they are fluent. It is this interpretation of the phenomenon of borrowing that will be the theoretical basis for the present study.

In his oft-quoted model of lexical borrowing, Haugen [1950: 212-213] defines the linguistic changes resulting from this phenomenon using two key terms - importation and substitution. The former is understood to have occurred when the original form and pronunciation of a particular feature are retained as part of the transfer process from the source language to the recipient language, while the latter is said to have occurred when the borrowed feature changes in form or pronunciation. Using degrees of morphemic and phonemic substitution - that is, the degree to which the form and pronunciation of the original feature have been adapted - as criteria, Haugen distinguishes eight distinct types of borrowings: loanwords, blended stems, derivational blends, compound blends, loan homonyms, loan synonyms due to semantic displacements, loan synonyms due to semantic confusions, and loan translations (see Winford [2003: 43-46] for a concise but clear summary of these categories of borrowing). Three of these - loanwords, compound blends and loan translations - form the vast majority of borrowed features observed in the MEN Corpus and they will be the focus of the present study.

\section{The corpus-based approach}

The corpus-based approach is "a way of investigating language by observing large amounts of naturally-occurring, electronically-stored discourse, using software which selects, sorts, matches, counts and calculates" (Hunston and Francis [2000: 15]). The present study utilises this approach in order to examine how words and phrases of Malay origin are used in ME. The data for the study were extracted from the MEN Corpus using WordSmith Tools, a software package which generates, most crucially for my needs, lists of all the words that occur in the corpus, and concordance displays of specific search words. The word lists revealed a wide range of Malay borrowings, many of which had not been identified in previous studies of ME, while the concordance displays allowed me to examine these features in context. 
By analysing the concordance display of a particular feature, I was able to establish the following: (1) the meaning(s) of the feature as used in ME; (2) the word class(es) ME users assign to it; (3) derived and inflected forms of the feature and their meanings; and (4) citations which illustrate the different usages of the feature. Using this information, I have constructed dictionary entries for the features identified. This procedure will become clearer when we come to the section on the codification of the ME lexicon.

In total, 264 lexical features of Malay origin were identified and examined. Table 1 provides an overview of the distribution of these features across different semantic fields. The corresponding dictionary entries are presented in the appendix. In the next three sections, I shall describe the diverse processes involved in the incorporation of loanwords, compound blends and loan translations into ME.

\begin{tabular}{|c|c|c|c|}
\hline Semantic fields & $\begin{array}{l}\text { Loanwords } \\
(\mathrm{n}=222)\end{array}$ & $\begin{array}{l}\text { Compound blends } \\
(\mathrm{n}=34)\end{array}$ & $\begin{array}{l}\text { Loan translations } \\
(\mathrm{n}=8)\end{array}$ \\
\hline \multicolumn{4}{|l|}{ Food $(n=79)$} \\
\hline Food items & $\begin{array}{l}\text { asam pedas } \\
\text { ayam pongteh } \\
\text { bubur lambuk/lambok } \\
\text { gulai tempoyak } \\
\text { kacang } \\
\text { kerabu } \\
\text { kerisik } \\
\text { ketupat } \\
\text { lontong } \\
\text { mee goreng } \\
\text { mee rebus } \\
\text { nasi briyani } \\
\text { nasi kerabu } \\
\text { nasi lemak } \\
\text { nasi ulam } \\
\text { rendang } \\
\text { rojak "spicy salad"* } \\
\text { roti } \\
\text { roti canai } \\
\text { roti jala } \\
\text { roti kaya } \\
\text { sambal } \\
\text { sambal belacan } \\
\text { sambal ikan bilis } \\
\text { sambal petai } \\
\text { sambal tempoyak } \\
\text { sambal udang petai } \\
\text { soto } \\
\text { ulam }\end{array}$ & $\begin{array}{l}\text { beef rending } \\
\text { briyani rice } \\
\text { chicken rendang } \\
\text { naan bread } \\
\text { pongteh chicken/ } \\
\text { chicken pongteh }\end{array}$ & \\
\hline $\begin{array}{l}\text { Sweets and } \\
\text { beverages }\end{array}$ & $\begin{array}{l}\text { ais kacang } \\
\text { bubur } \\
\text { bubur cha cha } \\
\text { bubur kacang } \\
\text { bubur pulut hitam } \\
\text { kaya } \\
\text { kuih } \\
\text { kuih bahulu } \\
\text { kuih bangkit }\end{array}$ & $\begin{array}{l}\text { ice kacang } \\
\text { pandan jelly }\end{array}$ & \\
\hline
\end{tabular}




\begin{tabular}{|c|c|c|c|}
\hline & $\begin{array}{l}\text { kuih kapit } \\
\text { putu beras } \\
\text { putu kacang } \\
\text { tapai } \\
\text { tapai pulut } \\
\text { tapai ubi } \\
\text { teh tarik }\end{array}$ & & \\
\hline \multirow[t]{2}{*}{$\begin{array}{l}\text { Fruit, vegetables, } \\
\text { herbs and spices }\end{array}$} & $\begin{array}{l}\text { bunga kantan } \\
\text { ciku } \\
\text { daun kesum } \\
\text { daun mambu } \\
\text { daun salam } \\
\text { duku langsat } \\
\text { kangkung } \\
\text { kunyit } \\
\text { langsat } \\
\text { pandan }\end{array}$ & $\begin{array}{l}\text { pandan leaf } \\
\text { wet rempah }\end{array}$ & \\
\hline & $\begin{array}{l}\text { petai } \\
\text { rempah } \\
\text { serai }\end{array}$ & & \\
\hline $\begin{array}{l}\text { Dried, fermented } \\
\text { or preserved } \\
\text { foodstuffs }\end{array}$ & $\begin{array}{l}\text { belacan } \\
\text { budu } \\
\text { cincalok } \\
\text { ikan bilis "dried } \\
\text { anchovies" } \\
\text { tempe } \\
\text { tempoyak }\end{array}$ & & \\
\hline Fish and poultry & $\begin{array}{l}\text { bawal hitam } \\
\text { bawal putih } \\
\text { ikan kembung } \\
\text { ikan tenggiri } \\
\text { ikan terubok }\end{array}$ & kampung chicken & \\
\hline \multicolumn{4}{|c|}{ Social and recreational activities $(n=37)$} \\
\hline Games and sports & $\begin{array}{l}\text { congkak } \\
\text { gasing } \\
\text { gasing pangkah } \\
\text { gasing uri } \\
\text { sepak takraw } \\
\text { silat } \\
\text { silat olahraga } \\
\text { wau } \\
\text { wau bulan }\end{array}$ & & \\
\hline $\begin{array}{l}\text { Music, song and } \\
\text { dance }\end{array}$ & $\begin{array}{l}\text { dikir barat } \\
\text { gamelan } \\
\text { joget } \\
\text { keroncong/kroncong } \\
\text { ronggeng } \\
\text { zapin }\end{array}$ & & \\
\hline Weddings & $\begin{array}{l}\text { bunga manggar } \\
\text { bunga telur } \\
\text { pelamin }\end{array}$ & bersanding ceremony & \\
\hline Feasting & $\begin{array}{l}\text { kenduri } \\
\text { makan } \\
\text { makan kecil }\end{array}$ & thanksgiving kenduri & \\
\hline
\end{tabular}




\begin{tabular}{|c|c|c|c|}
\hline $\begin{array}{l}\text { Musical } \\
\text { instruments }\end{array}$ & $\begin{array}{l}\text { kompang } \\
\text { rebab } \\
\text { rebana } \\
\text { rebana ubi } \\
\end{array}$ & & \\
\hline Theatre & $\begin{array}{l}\text { wayang } \\
\text { wayang kulit } \\
\text { wayang peranakan }\end{array}$ & & \\
\hline Poetry & $\begin{array}{l}\text { pantun } \\
\text { sajak } \\
\text { syair }\end{array}$ & & \\
\hline Performers & dalang & kompang troupe & \\
\hline Others & & $\begin{array}{l}\text { batik art } \\
\text { batik painting }\end{array}$ & \\
\hline \multicolumn{4}{|l|}{ Islam $(n=29)$} \\
\hline $\begin{array}{l}\text { Practices and } \\
\text { events }\end{array}$ & $\begin{array}{l}\text { (ber)buka puasa } \\
\text { Hari Raya/Hari Raya } \\
\text { Puasa/Hari Raya } \\
\text { Aidilfitri } \\
\text { umrah } \\
\end{array}$ & $\begin{array}{l}\text { Isyak prayer } \\
\text { Subuh prayer } \\
\text { terawih prayer }\end{array}$ & Friday prayer \\
\hline Officials & $\begin{array}{l}\text { imam } \\
\text { kadi } \\
\text { ulama/ulamak } \\
\text { ustaz } \\
\text { ustazah } \\
\text { wali } \\
\end{array}$ & & \\
\hline Islamic principles & $\begin{array}{l}\text { halal } \\
\text { non-halal } \\
\text { haram } \\
\text { khalwat } \\
\text { syariah } \\
\text { zina } \\
\end{array}$ & & \\
\hline Places & $\begin{array}{l}\text { (sekolah) pondok } \\
\text { "Islamic school" } \\
\text { madrasah } \\
\text { surau } \\
\end{array}$ & pondok school & \\
\hline Utterances & $\begin{array}{l}\text { Alhamdulillah/ } \\
\text { alhamdullilah/ } \\
\text { Alhamdullillah } \\
\text { Insyaallah/InsyaAllah/ } \\
\text { Insya-Allah/insyallah } \\
\end{array}$ & & God willing \\
\hline Calendar & $\begin{array}{l}\text { Ramadan/Ramadhan } \\
\text { Syawal }\end{array}$ & & \\
\hline Titles & $\begin{array}{l}\text { Hajah/Hajjah } \\
\text { Haji }\end{array}$ & & \\
\hline \multicolumn{4}{|c|}{ People and titles $(n=25)$} \\
\hline $\begin{array}{l}\text { Formal and } \\
\text { informal } \\
\text { categories }\end{array}$ & $\begin{array}{l}\text { baba } \\
\text { bumiput(e)ra } \\
\text { Muslim bumiput(e)ra } \\
\text { non-bumiput(e)ra } \\
\text { non-Muslim } \\
\text { bumiput(e)ra } \\
\text { mamak }\end{array}$ & & \\
\hline
\end{tabular}




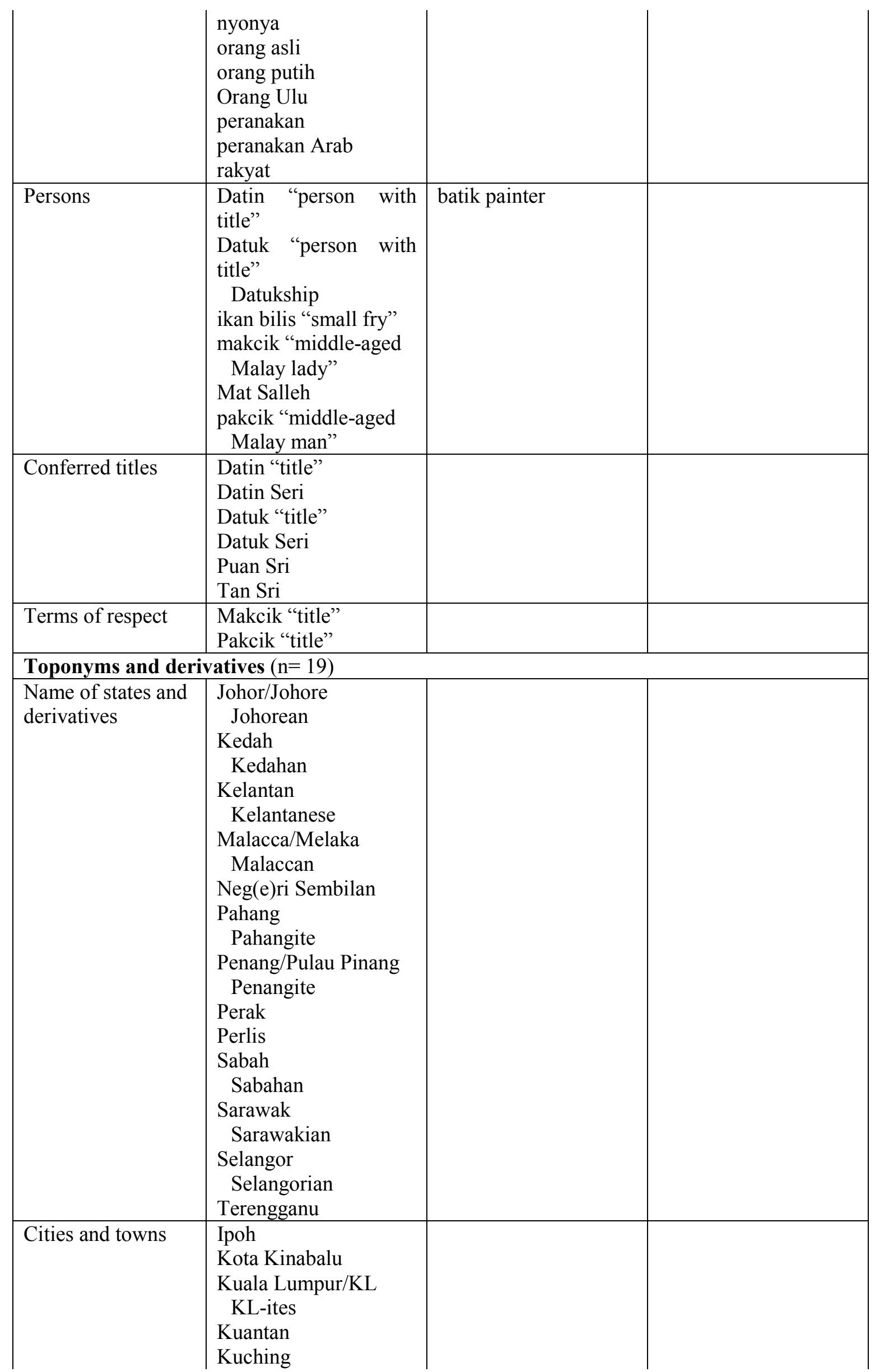




\begin{tabular}{|c|c|c|c|}
\hline & Muar & & \\
\hline \multicolumn{4}{|c|}{ Government, administration and the monarchy $(\mathrm{n}=18)$} \\
\hline Bodies & $\begin{array}{l}\text { (Lembaga) Tabung } \\
\text { Haji } \\
\text { Dewan Negara } \\
\text { Dewan Rakyat }\end{array}$ & $\begin{array}{l}\text { Orang Asli Affairs } \\
\text { Department/ } \\
\text { Department of Orang } \\
\text { Asli Affairs } \\
\text { Tabung Haji Board }\end{array}$ & $\begin{array}{l}\text { Islamic Affairs } \\
\text { Council/ } \\
\text { Islamic Council/ } \\
\text { Islamic Religious } \\
\text { Council } \\
\text { Islamic Affairs } \\
\text { Department } \\
\text { Islamic Religious } \\
\text { Department } \\
\text { Malaysian Islamic } \\
\text { Economic } \\
\text { Development } \\
\text { Foundation } \\
\end{array}$ \\
\hline Positions & $\begin{array}{l}\text { Datuk Bandar } \\
\text { Menteri Besar } \\
\text { Raja } \\
\text { Raja Permaisuri } \\
\quad \text { Agong } \\
\text { Sultan } \\
\text { wakil rakyat } \\
\text { Yang di-Pertua } \\
\quad \text { Neg(e)ri } \\
\text { Yang di-Pertuan } \\
\quad \text { Agong } \\
\text { Yang di-Pertuan Besar }\end{array}$ & & \\
\hline \multicolumn{4}{|l|}{ Clothing $(\mathrm{n}=15)$} \\
\hline Attire & $\begin{array}{l}\text { (baju) kebaya } \\
\text { baju Kedah } \\
\text { baju kurung } \\
\text { baju Melayu } \\
\text { batik sarong } \\
\text { sarong/sarung }\end{array}$ & & \\
\hline Accessories & $\begin{array}{l}\text { ibu kerongsang } \\
\text { kerongsang } \\
\text { selendang } \\
\text { songkok } \\
\text { tudung }\end{array}$ & & \\
\hline Textiles & $\begin{array}{l}\text { (kain) songket } \\
\text { batik }\end{array}$ & $\begin{array}{l}\text { batik cloth } \\
\text { saree cloth }\end{array}$ & \\
\hline \multicolumn{4}{|c|}{ Folk religion $(\mathrm{n}=10)$} \\
\hline Evil spirits & $\begin{array}{l}\text { hantu } \\
\text { jembalang } \\
\text { orang minyak } \\
\text { pontianak }\end{array}$ & & \\
\hline $\begin{array}{l}\text { Spiritual } \\
\text { treatments }\end{array}$ & $\begin{array}{l}\text { air jampi } \\
\text { jampi } \\
\text { kemenyan }\end{array}$ & & \\
\hline Spiritual healers & $\begin{array}{l}\text { bomoh } \\
\text { dukun } \\
\text { pawang }\end{array}$ & & \\
\hline \multicolumn{4}{|c|}{ Miscellaneous $(\mathrm{n}=32)$} \\
\hline Spaces & kampung & kampung house & night market \\
\hline
\end{tabular}




\begin{tabular}{|l|l|l|l|} 
& $\begin{array}{l}\text { pasar malam } \\
\text { pasar tani } \\
\text { pondok "hut" } \\
\text { pondok polis } \\
\text { ulu }\end{array}$ & $\begin{array}{l}\text { Malay kampung } \\
\text { mamak stall } \\
\text { nasi lemak stall }\end{array}$ & \\
\hline Behavioural terms & $\begin{array}{l}\text { gatal } \\
\text { jaguh kampung } \\
\text { muhibbah } \\
\text { tidak apa }\end{array}$ & $\begin{array}{l}\text { Malaysia boleh spirit } \\
\text { Merdeka spirit } \\
\text { tidak apa attitude }\end{array}$ & \\
\hline $\begin{array}{l}\text { Tools and objects } \\
\text { in the house }\end{array}$ & $\begin{array}{l}\text { parang } \\
\text { rotan "cane" }\end{array}$ & $\begin{array}{l}\text { pandan mat } \\
\text { mengkuang mat }\end{array}$ & $\begin{array}{l}\text { outrage ... modesty } \\
\text { outraging } \\
\text { modesty } \\
\text { carry out caning } \\
\text { Law }\end{array}$ \\
$\begin{array}{l}\text { sentence," } \\
\text { "judicially- } \\
\text { sanctioned caning" }\end{array}$ \\
\hline Others & $\begin{array}{l}\text { adat } \\
\text { balik kampung } \\
\text { dadah } \\
\text { gotong-royong } \\
\text { Jawi } \\
\text { rojak "hodgepodge" } \\
\text { rotan "climbing plant" }\end{array}$ & & rice bowl \\
\hline
\end{tabular}

Table 1. Distribution of features borrowed from Malay

* Some lexical items (datin, datuk, ikan bilis, makcik, pakcik, pondok, rojak and rotan) appear in more than one semantic field as they have more than one sense. These items are glossed to avoid confusion.

\section{Loanwords}

In ME, the most common forms of Malay borrowings are loanwords - simple and compound loanwords account for approximately 84 per cent of the features identified in this study (see Table 1). This figure does not necessarily reflect the actual percentage of loanwords as a proportion of total Malay borrowings in ME, but it does indicate that importation of simple and compound words is by far the most productive way through which the lexicon of ME has been enriched as a result of its contact with Malay.

At the outset, it is essential to specify that although all of the features listed in Table 1 came into ME from Malay, some of them actually have non-Malay roots. The list of loanwords in Table 1 includes a number of features that contain distinctly Arabic morphemes. Several other loanwords have components that originated in languages such as Hindustani, Tamil, Javanese and Baba Malay. For the purpose of this study, we shall treat these features as Malay borrowings. This is because these loanwords were not imported directly into ME from either Arabic or Tamil or Javanese. Instead, they were borrowed first into Malay, before entering the lexicon of ME. To illustrate, Arabic words like حرام (halal or halaal), (haram), إمام (imam), شريعة (qadi), عمرة (syaria or sari'ah), and (umrah) were transferred into the Malay language where they gained currency before they were borrowed into ME. The indirect route that these features took is obvious, not only because Arabic does not come into 
direct contact with English in Malaysia but also because these words have a longer history in Malay compared to in ME.

For the most part, the reproduction of Malay words in ME involves complete morphemic importation with little phonemic substitution. It is recognised that the present study is not designed to detect possible phonemic substitution of Malay loanwords given that the MEN Corpus comprises only written text and no phonological information about these loanwords can be derived. However, based on my informal observations of spoken ME and the fact that there is little orthographic adaptation in these loanwords, I would suggest that phonemic substitution in Malay loanwords is uncommon. Hence, simple words like baba, bubur, hantu, madrasah, pawang and zina; and compound words like ikan bilis, Mat Salleh, teh tarik, sepak takraw and wakil rakyat are reproduced in ME in their original Malay spelling.

The lack of phonemic substitution in Malay loanwords is not particularly unusual, especially if one considers the fact that ME speakers, on the whole, are fluent in Malay, whether or not they speak it as their first language. Malaysians born since the 1960s are especially proficient in the language as they were required to learn it in school, at the very least as one of the subjects of the curriculum. Many would have gone to Malay-medium primary and secondary schools, and for these people, the national language would have been acquired in childhood and be one of the languages in which they are most proficient as adults. In short, ME speakers' familiarity with the Malay language is such that they are generally able to reproduce Malay loanwords without modifying any of the original phonological sequences. Such "phonemic importation" is characteristic of bilingual speech communities in which knowledge of the source language is attained in childhood (see Haugen [1950: 216217] and McMahon [1994: 205-206] for a review of other contact conditions where borrowers' familiarity with the source language has been found to reduce the likelihood of their modifying words borrowed from it).

The few occurrences of orthographic adaptation and phonemic substitution in Malay loanwords involve toponyms, such as Johore <Malay Johor $>$, Malacca $<$ Malay Melaka $>$, Negri Sembilan <Malay Negeri Sembilan>, and Penang <Malay Pulau Pinang $>.^{5}$ In his analysis of ME, Schneider [2003b: 52] suggests that toponyms such as these are "the earliest and most persistent foreign elements that entered English." $\mathrm{He}$ attributes these earliest borrowings to the settlers - the earlier groups of English-speaking traders, missionaries, colonial officers and civil servants who resided in the Malay Peninsula during the initial phases of contact between English and the local languages. This explanation accounts for the phonological adaptations, or in Tan's [2001: 165] words, "the anglicising tendency" seen in these toponyms. Not many members of Schneider's [2003a and 2003b] settler strand were familiar with Malay. It is therefore likely that their pronunciation of these place names was influenced by the English phonological system. Their versions of these toponyms were transmitted through their interaction with (the English-speaking members of) the local communities. Because the settlers occupied positions of power, it is likely that their version of local place names became the norm - at least for administrative purposes. Today, half a century after the departure of the colonial government, toponyms such as Johore, Malacca and Penang are still widely-used although scholars like Tan [2001: 165] have noted that the pronunciations of these words have changed as a result of the nativisation of these words to the phonological patterns of ME. He illustrates these phases of change using the following examples $^{6}$ (Tan [2001: 165-166]):

(Pulau) Pinang/Penang: Malay /'pinay/ $\rightarrow$ RP /pi'næy/ $\rightarrow$ SME /pi'ncy/

Melaka/Malacca: Malay /mə'lakə/ $\rightarrow$ RP /mə'lækə/ $\rightarrow$ SME /mə'lekə/

\footnotetext{
${ }^{5}$ In all these cases, the original Malay toponyms are also in currency in ME (see these entries in the appendix).

${ }^{6}$ In Tan's [2001: 165-166] examples, SME stands for Singaporean and Malaysian English.
} 


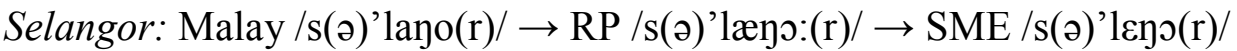

In addition to the toponyms listed above, there are a few other Malay loanwords that have more than one spelling in the MEN Corpus. These include Alhamdulillah (alhamdullilah, Alhamdullillah) $<$ Malay alhamdulillah $>$; bubur lambok (lambuk) $<$ Malay bubur lambuk $>$; Insyaallah (InsyaAllah, Insya-Allah, insyallah) $<$ Malay insya-Allah $>$; keroncong (kroncong) $<$ Malay keroncong $>$; Ramadan (Ramadhan) $<$ Malay Ramadan $>$; and ulama (ulamak) $<$ Malay ulama $>$. Some of these variants are related to the difficulty in representing words of Arabic origin in Roman letters (e.g., alhamdulillah, insya-Allah and Ramadan). This is due to the spelling assimilation that occurs when the source language is not represented using the Roman alphabet. Other variants are the results of changes in Malay orthography over the years and the introduction of the Sistem Ejaan Baru "New Spelling System" in the 1970s (e.g., bubur lambuk and keroncong). Variants like these exist not only in ME but also in the Malay language, and therefore cannot be regarded as evidence of nativisation.

Another characteristic of the process of borrowing in ME is the "semantic modification"8 that accompanies the incorporation of certain Malay words into this variety of English. This is to say, a Malay word that is imported into ME does not always retain all of its original meanings: often only a single sense is transferred, and sometimes the meaning in ME conveys a cultural specificity that is absent in the original range of meanings.

Table 2 compares the meanings of several words in Malay and ME. In the borrowing of the words dadah, gatal, kacang, roti and ulu, semantic restriction occurs. For example, the word gatal in Malay can mean both "itchy" (a sensation) and "mischievous and flirtatious" (commonly associated with lecherous men), but in ME it appears to be used only to express the latter meaning. Similarly, the Malay word kacang has several senses - "peas," "beans," "lentils" and "nuts" - but in ME the word most often refers to "roasted nuts, usually eaten as a snack." In the borrowing of these words, only one specific sense seems to have been transferred, usually a sense that cannot be concisely expressed using existing English words.

\begin{tabular}{|c|c|c|}
\hline Lexical item & Meaning(s) in Malay & Meaning(s) in ME \\
\hline dadah & $\begin{array}{l}n .1 \text { A substance used as a } \\
\text { component of a medication. } 2 \text { A } \\
\text { chemical substance, such as a } \\
\text { narcotic or hallucinogen, that } \\
\text { affects the central nervous } \\
\text { system. }\end{array}$ & $\begin{array}{l}n \text {. A chemical substance, such as } \\
\text { a narcotic or hallucinogen, that } \\
\text { affects the central nervous } \\
\text { system. }\end{array}$ \\
\hline gatal & $\begin{array}{l}\text { a. } 1 \text { Itchy. } 2 \text { Mischievous and } \\
\text { flirtatious, usually of lecherous } \\
\text { men. }\end{array}$ & $\begin{array}{l}\text { a. Mischievous and flirtatious, } \\
\text { usually of lecherous men. }\end{array}$ \\
\hline kacang & $n$. Peas, beans, lentils or nuts. & $\begin{array}{l}n \text {. Roasted nuts, usually eaten as a } \\
\text { snack. }\end{array}$ \\
\hline rakyat & $\begin{array}{l}n .1 \text { The citizens of a state or } \\
\text { country. } 2 \text { The common people } \\
\text { (as opposed to the government or } \\
\text { the aristocracy). }\end{array}$ & $\begin{array}{l}n . \text { The common people (as } \\
\text { opposed to the government or the } \\
\text { aristocracy) of Malaysia. }\end{array}$ \\
\hline
\end{tabular}

\footnotetext{
${ }^{7}$ The Sistem Ejaan Baru was one of the results of the attempt by the Malaysian and Indonesian governments to create a standardised spelling system for the official languages of Malaysia and Indonesia.

8 This phenomenon is also observed in Malay loanwords in colloquial English (see Arfah [1998]), and in Hokkien and Teochew as spoken in Singapore (see $\mathrm{Ng}$ and Tan [2009]).
} 


\begin{tabular}{|c|c|c|}
\hline rotan & $\begin{array}{l}n . \mathbf{1} \text { Any of various climbing } \\
\text { plants of tropical Asia, having } \\
\text { long, tough, slender stems. } \mathbf{2} \text { The } \\
\text { stems of any of these plants, used } \\
\text { to make wickerwork, canes, and } \\
\text { furniture. } 3 \text { A cane made from } \\
\text { these plants. } 4 \text { Judicially- } \\
\text { sanctioned caning in Malaysia. }\end{array}$ & $\begin{array}{l}n .1 \text { A rattan cane used for } \\
\text { inflicting judicially-sanctioned } \\
\text { corporal punishment in Malaysia. } \\
2 \text { Any of various climbing plants } \\
\text { of tropical Asia, having long, } \\
\text { tough, slender stems. } 3 \text { (rare) A } \\
\text { cane. } 4 \text { (rare) Judicially- } \\
\text { sanctioned caning in Malaysia. }\end{array}$ \\
\hline roti & n. Bread & $\begin{array}{l}n \text {. Bread, usually the local version } \\
\text { of a white loaf, which is slightly } \\
\text { sweet and has a very soft texture. }\end{array}$ \\
\hline $\begin{array}{l}\text { ulu } \\
<\text { Malay }\end{array}$ & $\begin{array}{l}\text { n. } 1 \text { The source of a river. } 2 \\
\text { Inland area. } \mathbf{3} \text { The handle of a } \\
\text { tool, knife, etc. }\end{array}$ & $\begin{array}{l}n . \text { A provincial place, back } \\
\text { country. }\end{array}$ \\
\hline
\end{tabular}

Table 2. Semantic modification of Malay loanwords

In some cases, the transfer from Malay to ME gives the loanwords involved a novel cultural specificity that is missing in the meanings of these words in the original language. I shall illustrate this point using the loanword rotan. Figure 1 is the edited ${ }^{9}$ concordance display of rotan from the MEN Corpus. There are four main senses of rotan in Malay (see rotan in Table 2) and three of these appear in the MEN Corpus. The reference to "any of various climbing plants of tropical Asia, having long, tough, slender stems" is seen in lines 2 and 3 of the concordance display, the reference to "a cane" in line 1, and the reference to "judiciallysanctioned caning" in line 12. The primary sense of rotan in ME, however, is "a rattan cane used for inflicting judicially-sanctioned corporal punishment in Malaysia," and this sense occurs nineteen times in the MEN Corpus (see lines 4-11 and lines 13-23 in Figure 1). This sense of rotan in ME has a cultural-specificity - not just any cane but one that is used to carry out court-ordered canings - and it is this specificity that is not in evidence in the range of meanings of rotan in Malay. The reference to this meaning is encapsulated in the phrase "stroke(s) of the rotan" (see Figure 1), which is a nativised version of the English phrase "stroke(s) of the cane" - the English phrase is retained but for the substitution of rotan for cane.

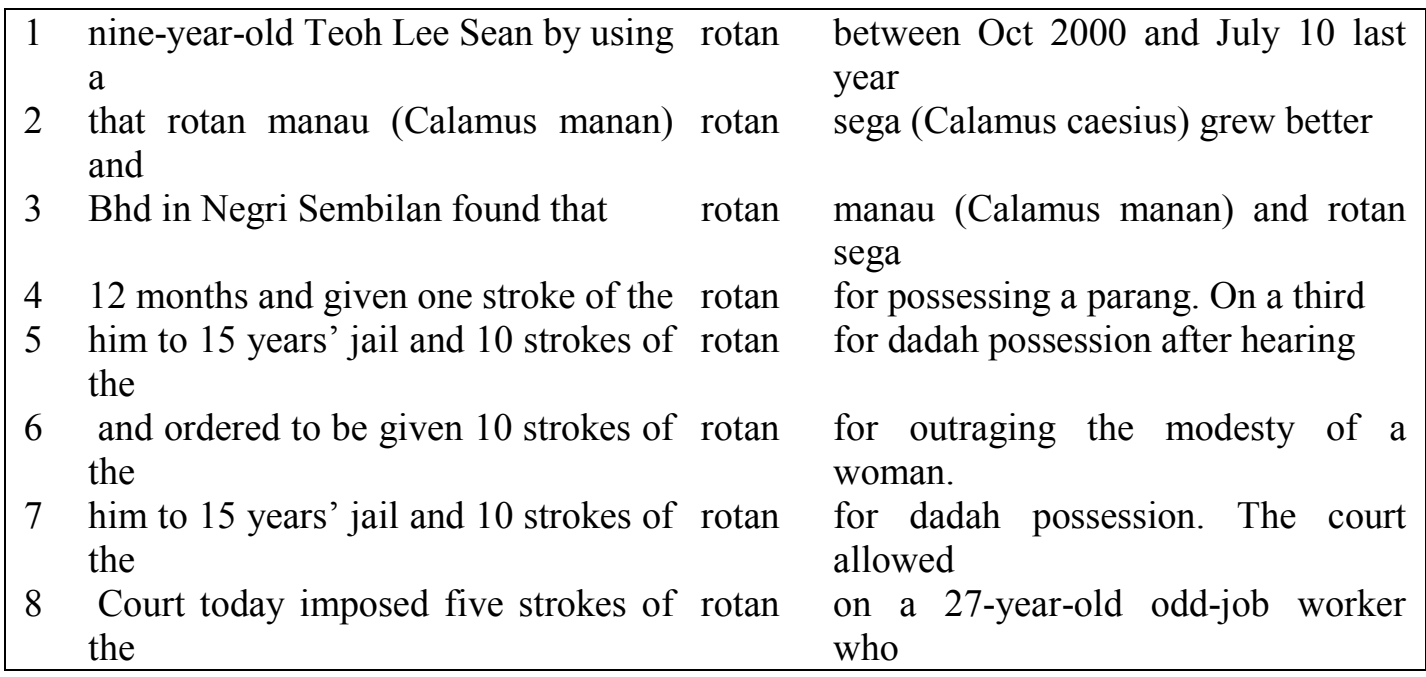

\footnotetext{
${ }^{9}$ In several concordance lines, the word rotan appears as part of a proper noun. These lines were deleted.
} 


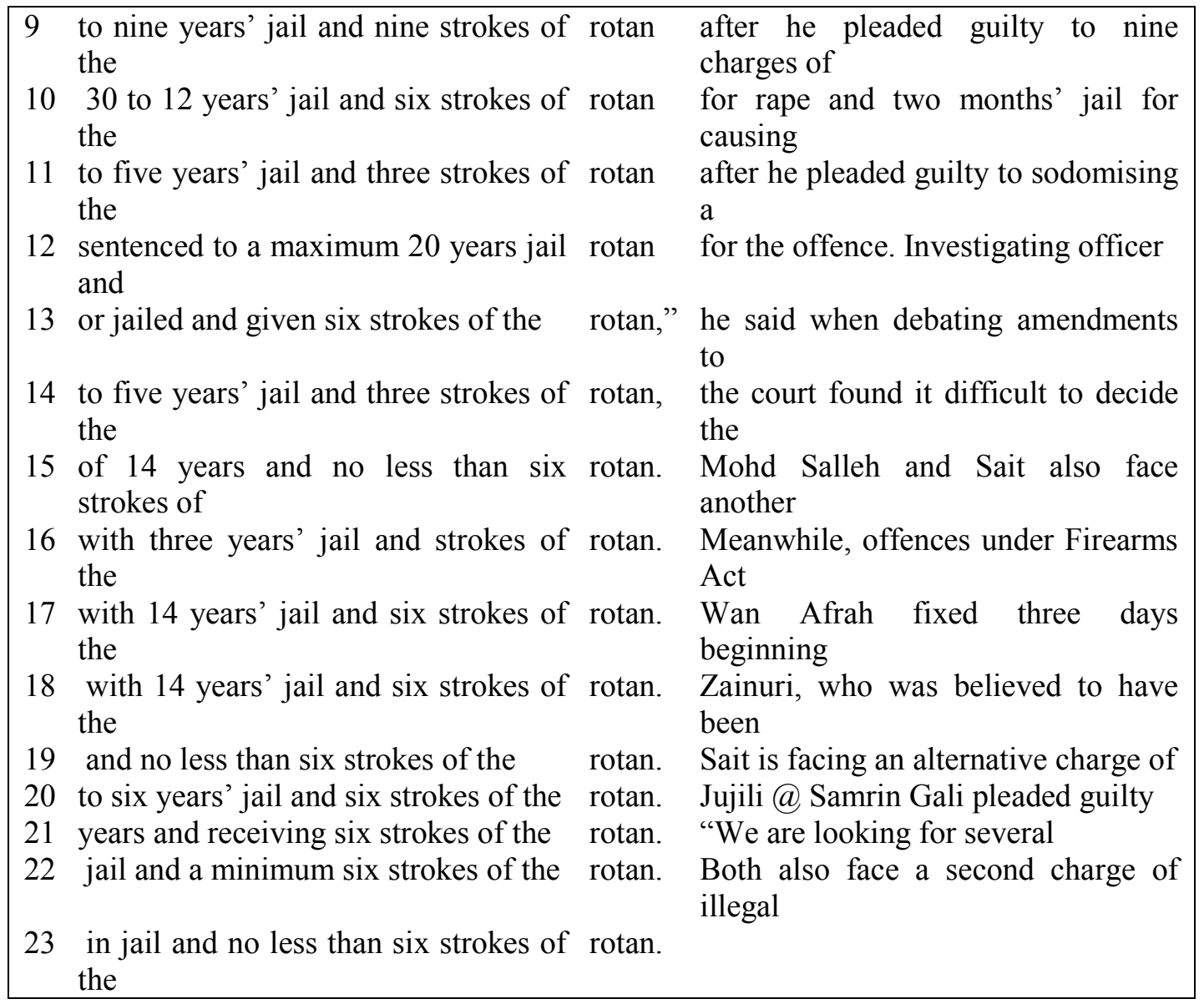

\section{Figure 1. Edited concordance display of rotan from the MEN Corpus}

The same cultural specificity is observed in the meaning of rakyat in ME. In Malay, the word rakyat has two main senses: "the citizens of a state or country" and "the commoners (as opposed to the government or the aristocracy)." Neither of these senses is limited to the context of Malaysia, and so, in Malay, constructions like rakyat Amerika "American citizens" or rakyat asing "foreign citizens" are as acceptable as rakyat Malaysia "Malaysian citizens." However, if we examine the edited ${ }^{10}$ concordance display of rakyat from the MEN Corpus (see Figure 2), we see a very apparent restriction in the way that the word in used. In ME, rakyat denotes the people of Malaysia - either with reference to their citizenship or their place of residence or to distinguish them from the government or the aristocrats.

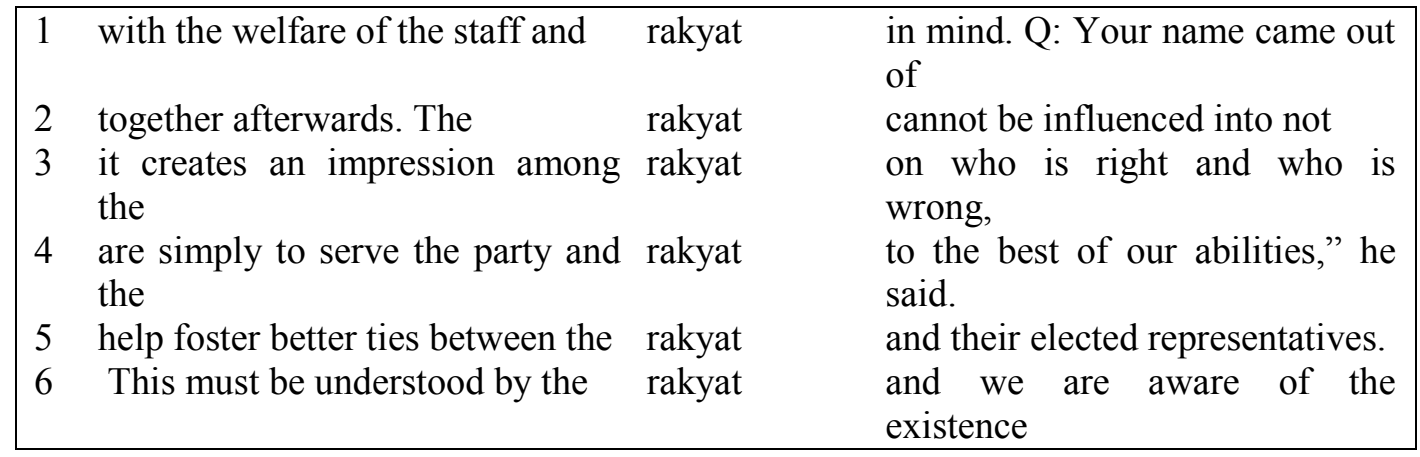

\footnotetext{
${ }^{10}$ The concordance lines of wakil rakyat, Dewan Rakyat and proper nouns that include the word rakyat are removed.
} 


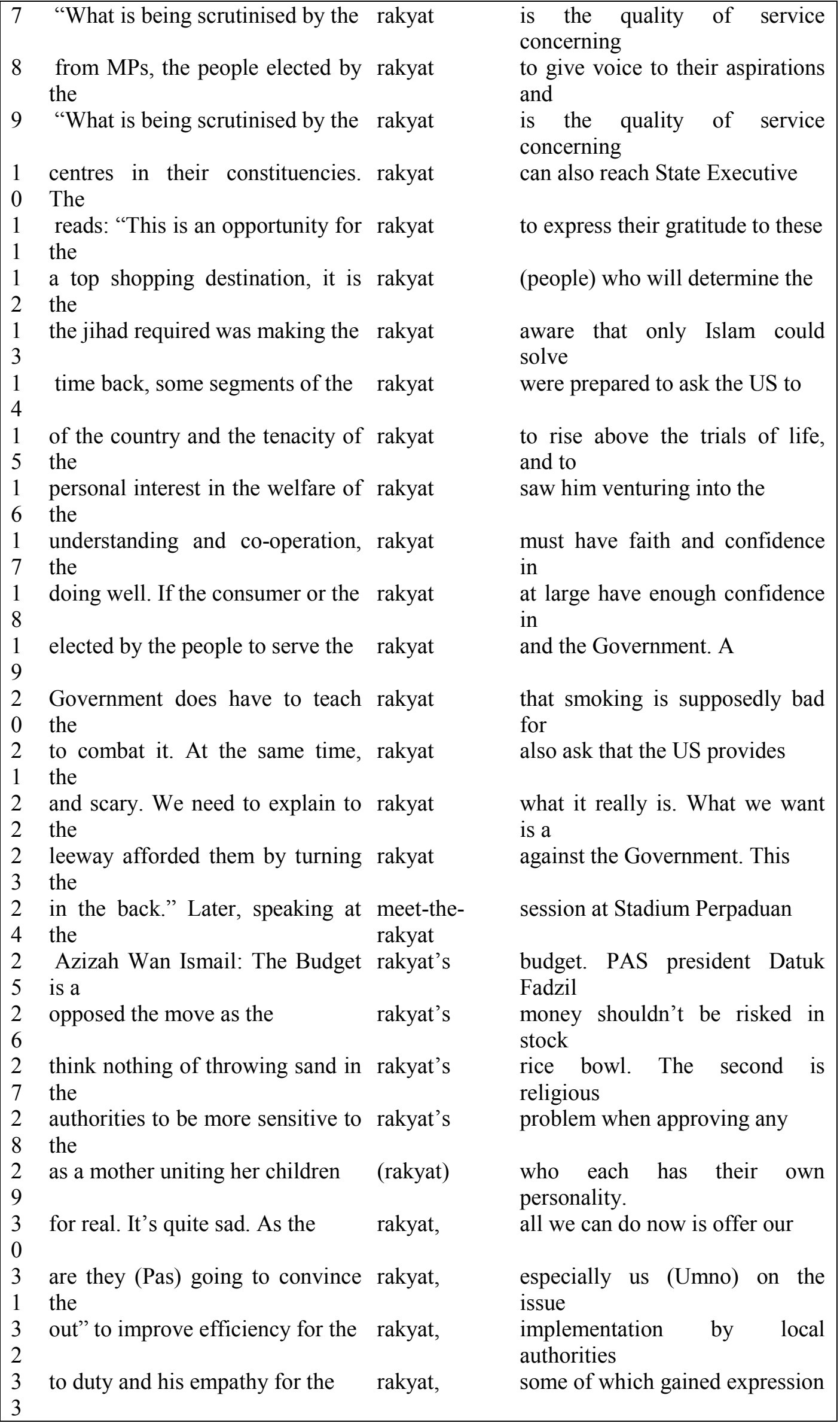




\begin{tabular}{|c|c|c|c|}
\hline 3 & of his people, especially the & rakyat. & He always reminded us how \\
\hline $\begin{array}{l}3 \\
5\end{array}$ & $\begin{array}{l}\text { governmental organisations and } \\
\text { the }\end{array}$ & rakyat. & Dennis J. Parker of Middlesex \\
\hline 3 & $\begin{array}{l}\text { one that was not going to benefit } \\
\text { the }\end{array}$ & rakyat. & $\begin{array}{l}\text { "If they rule this country, the } \\
\text { people }\end{array}$ \\
\hline 3 & should be utilised to benefit the & rakyat. & When undertaking mega or big \\
\hline 3 & was generally lauded by the & rakyat. & $\begin{array}{l}\text { Dr Mohd Khir's latest decision } \\
\text { to }\end{array}$ \\
\hline $\begin{array}{l}3 \\
9\end{array}$ & had been felt most keenly by the & rakyat. & $\begin{array}{l}\text { "It's hoped that with new } \\
\text { measures }\end{array}$ \\
\hline 4 & $\begin{array}{l}\text { of educational opportunities for } \\
\text { the }\end{array}$ & rakyat. & Doubtless, this package helps the \\
\hline 4 & $\begin{array}{l}\text { that look up to the aspirations of } \\
\text { the }\end{array}$ & rakyat. & And also to promote forward \\
\hline 4 & way against the wishes of the & rakyat. & $\begin{array}{l}\text { "The } 19 \text { had gone to the extend } \\
\text { of }\end{array}$ \\
\hline 4 & the MPs were representing the & rakyat. & "If we Yang Berhormat find it \\
\hline 4 & $\begin{array}{l}\text { Sultan, he was always close to } \\
\text { the }\end{array}$ & rakyat. & When he was appointed King, he \\
\hline 4 & $\begin{array}{l}\text { party will explain its concept to } \\
\text { the }\end{array}$ & rakyat. & "Often, the image is one that is \\
\hline
\end{tabular}

Figure 2. Edited concordance display of rakyat from the MEN Corpus

In addition to semantic adaptations, certain Malay loanwords are also subject to morphosyntactic integration. ME users sometimes create new grammatical categories and novel word forms by adding English inflectional and derivational morphemes to words of Malay origin. By far the most productive inflectional morpheme in ME is the plural $-s$ suffix, which is regularly utilised to indicate plurality in count nouns. Examples of Malay loanwords that have been given a plural form are bomoh (plural bomohs), bumiputera/bumiputra (plural bumiputeras/bumiputras), datuk (plural datuks), kerongsang (plural kerongsangs), nyonya (plural nyonyas), pondok (plural pondoks), and ulama/ulamak (plural ulamas/ulamaks). The use of some of these plural forms in ME can be seen in the appendix.

Besides inflecting Malay loanwords to generate plural word forms, ME users also employ several derivational morphemes to create new words. The most common derivational morphemes used include: (1) the prefix non- indicating "not" (e.g., non-halal "not hahal," and non-bumiputera/non-bumiputra "not bumiputera/bumiputra"); (2) the suffixes -ean, -an, ese, -ite and -ian indicating "residents of a state" (e.g., Johorean "resident of Johor/Johore," Kedahan "resident of Kedah," Kelantanese "resident of Kelantan," Penangite "resident of Penang," and Sarawakian "resident of Sarawak"); and less commonly, (3) the suffix -ship indicating "a state or condition" (e.g., Datukship "the state of having been awarded the title of Datuk"). The results of these inflectional and derivational processes are hybridized forms which, according to Winford [2003: 44], are not technically the immediate outcomes of borrowing but "are really due to the more general process of integrating loan items into the morphology of the recipient language." To put it differently, borrowers apply recipient language morphosyntactic processes to previously imported words so that these words behave more like original recipient language words. In the same vein, Tan [2001] postulates that such inflectional and derivational processes are indications that the loanwords have become nativised to the linguistic system of the recipient language. Following these scholars, I have 
categorised these hybrid lexical items, not as individual borrowings, but as inflected and derived forms based on Malay loanwords. As such, they are not accorded a separate entry in the appendix (see also Table 1) but are placed under the particular loanword out of which they evolved.

\section{Compound blends}

Compound blends form about 13 per cent of the total number of borrowed features identified in this study (see Table 1). These borrowings are exclusively nominal compounds: beef rendang $<$ Malay rendang daging $>$ "spicy beef dish," batik cloth $<$ Malay kain batik $>$ "traditional textile," pondok school $<$ Malay sekolah pondok $>$ "Islamic school," bersanding ceremony $<$ Malay majlis persandingan $>$ "Malay wedding ceremony," mamak stall $<$ Malay gerai (or warung) mamak> "stall run by an Indian Muslim," kampung chicken $<$ Malay ayam kampung> "a local breed of chicken," and mengkuang mat <Malay tikar mengkuang $>$ "mat made using a type of screw pine." In each of these cases, the ME user appears to have borrowed and broken down a Malay compound form into its component morphemes, imported one of them and replaced the other with an English equivalent. This process closely resembles the partial morphemic substitution that Haugen [1950: 219] describes.

The only apparent adaptation in the process involves the reversal of word order in the nominal phrase. The structure of a basic Malay nominal phrase is [head + modifier], as in ayam kampung ("chicken" + "village") "a local breed of chicken." In the process of borrowing, this structure is typically reversed to suit the [modifier + head] structure of a basic English nominal phrase. Hence, ayam kampung is borrowed as kampung chicken ("village" + "chicken"). In short, although these compound blends are modelled after Malay terms, they are often structurally adapted in order to nativise them to the structure of the English language.

Just as with some of the loanwords that we have seen, compound blends too can reflect the influences of languages other than Malay. The influence of Arabic can be seen in features such as Ishak prayer (Malay sembahyang Isyak, originally Arabic عشاء isha) and terawih prayer (Malay sembahyang terawih, originally Arabic تراويح terawih), while the influence of Indic languages is reflected in features such as briyani rice (Malay nasi briyani, originally Hindustani biryani), naan bread (Malay roti naan, originally Hindustani naan) and saree cloth (Malay kain sari, originally Sanskrit, Hindi, Urdu sari, saree).

The simultaneous contact between several languages can sometimes yield unexpected linguistic outcomes which reveal possible routes that the terms have taken in the process of being borrowed into ME. This will be demonstrated using the compound blend briyani rice. The Hindustani word, biryani, means "a spicy meat and rice dish." When this word was borrowed into the Malay language, it took on a few new forms - beriyani, nasi beriyani, briyani, and more commonly, nasi briyani. Briyani was phonemically adapted from biryani, while the Malay morpheme nasi "rice" was added to the name of the dish, most likely because names of rice dishes in the Malay language typically begin with the word nasi: for example, nasi tomato "tomato rice," nasi lemak "rice cooked in coconut milk," nasi ulam "rice with herbs," and so on. As the sense of "rice" is already included in the term biryani, nasi briyani is essentially a tautology, but this nativised form of biryani gained currency in Malay and was subsequently borrowed into ME. In contemporary ME, nasi briyani (loan word) and briyani rice (compound blend) are used interchangeably. Interestingly, the Hindustani loanword biryani is not as widespread - it appears only once in the MEN Corpus. So, although the ultimate source of briyani rice is the Hindustani word biryani, this study considers briyani rice to be a borrowing from Malay because the structure of this nominal 
compound suggests that at the initial stage of its metamorphosis, it had been nativised to the structure of the Malay language, and it is this nativised form that was borrowed into ME. Similarly, naan bread, saree cloth, Isyak prayer and terawih prayer are regarded as Malay borrowings despite the presence of non-Malay morphemes in these constructions.

\section{Loan translations}

Loan translations account for only 3 per cent of the total number of features of Malay origin identified in this study (see Table 1). As posited by Haugen [1950: 214], this group of lexical items shows total morphemic substitution in that the borrowers import the "structural pattern" of the compound form but replace each constituent morpheme with a corresponding English word. Friday prayer is therefore based on the Malay lexical item sembahyang Jumaat which has its roots in Arabic جمعة Jum'ah. As with compound blends, the [head + modifier] word order is reversed in the process of borrowing. There are, however, some inherent problems associated with the identification of loan translations in ME that should be highlighted.

First, it would be misleading to suggest that all the loan translations listed in Table 1 have forms that correspond perfectly to them in Malay. Rice bowl is an example of a loan translation whose Malay model does not quite match. Morphemically, the term rice bowl is closer to Mandarin 饭碗 fan wan (literally "rice bowl") than it is to Malay periuk nasi (literally "rice pot"). Semantically, however, rice bowl has more in common with Malay periuk nasi than it has with Mandarin 饭碗 fan wan. All three terms share a common meaning - "means of livelihood." In the MEN Corpus, however, rice bowl is also used as a metonymy for Kedah, the most important rice-producing state in Malaysia - as periuk nasi is used in Malay - and it is this sense of rice bowl that gives a hint of the influence of Malay. So although this paper considers rice bowl as a Malay borrowing, in reality, all that can be asserted in support of this claim is that this feature reflects possible influence from the Malay language.

The lexical item night market also poses some difficulty. Although there is a Malay model for this feature - pasar malam - the concept of a night market is prevalent in numerous other languages in many parts of Asia. In fact, night market occurs in many Asian varieties of English, primarily Singapore English and Hong Kong English. Although this study includes the feature as a Malay borrowing, it is entirely possible that it was created in other contact situations and was subsequently transmitted across Asia by merchants, traders, colonial officers and missionaries. In short, it is possible that the exact origin of this feature may never be ascertained.

Another controversy is related to the exact source of the expression God willing in ME. This paper classifies God willing as a loan translation of the Malay (originally Arabic) expression insyaallah. This is deduced primarily from the way that this expression is used in ME. The sentences below capture the contexts of the three occurrences of this term in the MEN Corpus:

1. "God willing, we will win the individual event. But we can only win two medals as the rules say each nation can only win two even if the third rider scores enough to win the bronze." (Quzandria Nur, Malaysian rider, commenting on her team members' chances of winning the individual equestrian event at the 2001 SEA Games in Kuala Lumpur) (The New Straits Times, 11 September 2001)

2. "His Majesty also said that with the prayers of everyone, God willing, he will be returning home soon." (Datuk Zubir Ali, the Grand Chamberlain of the Istana Negara 
on Sultan Salahuddin Abdul Aziz Shah's state of health after a surgery) (The Star, 10 October 2001)

3. "God willing, we will complete the negotiations by October. We have formed a task force (to look into this matter). We are supposed to complete (the talks) within the next two months." (Datuk Fuad Jaffar, president and chief executive officer of Tenaga Nasional Bhd on on-going negotiations between his company and Kapar Energy Ventures Sdn Bhd) (The Star, 3 August 2001)

As can be seen, God willing is generally used by Malays (who are constitutionally required to be Muslims). ${ }^{11}$ Furthermore, the term is usually used to prefix a statement of positive intent or aspiration - the same way that insyaallah is used in various Islamic contexts. I have therefore concluded that God willing in ME was modelled on insyaallah. The fact, however, is that the expression God willing can commonly be found in archaic or pious English. Whether this is just an example of an old English phrase that has been retained in ME despite having generally gone out of fashion in native varieties of English is a question to which I have not been able to give a conclusive answer. Perhaps all that can be said with regard to this feature is that while the form of the expression reflects its origin in archaic or pious English, the prevalence of its use in ME clearly reflects an Islamic context.

Clearly, the actual origin of loan translations in ME is not as easily determined as that of loanwords or even compound blends. For most of these features, it is not the presence of a corresponding Malay term that is most suggestive of the influence of the Malay language. Rather, it is the way that these features are used in ME.

\section{Codifying the lexicon of Malaysian English}

This is not by any means the first attempt at codifying the vocabulary of ME. In 1984, the SEAMEO Regional Language Centre based in Singapore produced a volume comprising four "mini-dictionaries" of Asian Englishes, one of which was ME. These dictionaries were ground-breaking, not least because they emphasised the independence of these new Englishes - the need to "sever those lexical origin bonds that too closely bind a language to daughter status of British English" (Johnson [1984: vii]). However, as these dictionaries were based on randomly collected citations, it is felt that there is a real need to reassess, this time with the assistance of a corpus, the potential for the codification of the lexicon of ME.

In exploiting the MEN corpus for lexicographic evidence, the focus of this study has been on extracting and highlighting recurrent lexical items whose origin can be traced to Malay. ${ }^{12}$ The concordance display of each item was studied for basic semantic and grammatical information, while its etymology was derived from various dictionaries. ${ }^{13}$ Based on these data, a dictionary entry was created. I shall demonstrate this procedure with the analysis of a well-known Malay loanword kampung. In order to obtain an overall understanding of how kampung is used in ME, it was necessary to examine the contexts of all the forms of the lexeme kampung. This was achieved by performing a wildcard search in Concord using the

\footnotetext{
${ }^{11}$ The Malaysian Constitution defines a Malay as a person who speaks the Malay language, practices Malay cultural traditions, and crucially, is a Muslim.

${ }^{12}$ See Tan [2008] for the codification of ME features borrowed from Chinese.

${ }^{13}$ In the course of this study, I have referred to the following dictionaries: Hobson-Jobson [Yule and Burnell], A Malay-English Dictionary (Romanised) [Wilkinson], Kamus Lanjutan Bahasa Malaysia-Bahasa Inggeris (Advanced Malay-English Dictionary) [Abd. Aziz Rahman], Kamus Dewan Edisi Ketiga (Dewan Dictionary, Third Edition) [Hajah Noresah bt. Baharom et al.], Dwibahasa Kamus Delta (Delta Bilingual Dictionary) [Lufti Abas and Awang Sariyan], Kamus Melayu Global (Global Malay Dictionary) [Hasan Hamzah], and OED Online [Simpson and Weiner].
} 
search word kampung*. The asterisk instructs Concord to disregard the end of the word and to locate all instances of words that begin with kampung. This search yielded 944 entries, the vast majority of which were proper nouns, specifically names of villages. These were deemed not very interesting and were deleted from the concordance display. A few collocations of kampung (e.g., balik kampung and jaguh kampung) were found to be distinctive enough to warrant separate analyses, and were thus excluded from this set of data. The remaining lines, 128 in total, can be viewed in Figure 3.

\begin{tabular}{|c|c|c|c|}
\hline 1 & $\begin{array}{l}\text { the young with better wages and a higher } \\
\text { standard of living. Yet the }\end{array}$ & kampung & $\begin{array}{l}\text { ambience remains undisturbed - at least } \\
\text { for now. Tucked in the }\end{array}$ \\
\hline 2 & $\begin{array}{l}\text { legend and myth of the kampung's } \\
\text { history and warriors while the }\end{array}$ & kampung & $\begin{array}{l}\text { and its friendly residents engender a } \\
\text { feeling of reliving the past }\end{array}$ \\
\hline 3 & $\begin{array}{l}\text { That was a key issue at that time. "I mean } \\
\text { when you stay in a }\end{array}$ & kampung & $\begin{array}{l}\text { and then suddenly people come and say } \\
\text { you are a squatter, you can }\end{array}$ \\
\hline 4 & $\begin{array}{l}\text { who deserves mention is one called only } \\
\text { Halim. Known as the }\end{array}$ & kampung & $\begin{array}{l}\text { artist to his peers, Halim enjoys painting } \\
\text { ducks, geese and all sorts }\end{array}$ \\
\hline 5 & $\begin{array}{l}\text { flooding in parts of the Bongawan } \\
\text { township while roads to four }\end{array}$ & kampung & $\begin{array}{l}\text { at nearby Membakut were submerged } \\
\text { under nearly one metre of }\end{array}$ \\
\hline 6 & $\begin{array}{l}\text { when I was young. I spent a few years of } \\
\text { my life in that }\end{array}$ & kampung & $\begin{array}{l}\text { before father decided to relocate the entire } \\
\text { family to Kampar, Ipoh }\end{array}$ \\
\hline 7 & $\begin{array}{l}\text { way for me. It's as if I've had a charmed } \\
\text { life." Looks like it. As a }\end{array}$ & kampung & $\begin{array}{l}\text { boy, he was surprised to be counted } \\
\text { among the few handpicked to }\end{array}$ \\
\hline 8 & $\begin{array}{l}\text { juicy, and as satisfying as the rest of the } \\
\text { simple dinner of tender }\end{array}$ & kampung & $\begin{array}{l}\text { chicken and vegetables. After dinner, we } \\
\text { went for a walk. }\end{array}$ \\
\hline 9 & $\begin{array}{l}\text { on the cob, suffice to say that a juicy } \\
\text { half-portion of scrumptious }\end{array}$ & kampung & $\begin{array}{l}\text { chicken leaves ravenous journalists } \\
\text { craving for more. Another }\end{array}$ \\
\hline 10 & $\begin{array}{l}\text { overdone. TCRS offers customers a } \\
\text { choice of ordinary chicken or }\end{array}$ & kampung & $\begin{array}{l}\text { chicken with a slight difference in prices. } \\
\text { Don't worry if you are }\end{array}$ \\
\hline 11 & $\begin{array}{l}\text { another housing estate in the Santubong } \\
\text { area under the organised }\end{array}$ & kampung & $\begin{array}{l}\text { concept. "The development will create } \\
\text { spin-off activities to benefi }\end{array}$ \\
\hline 12 & $\begin{array}{l}\text { adding fried freshwater prawns, said the } \\
\text { aroma reminded him of }\end{array}$ & kampung & $\begin{array}{l}\text { cooking. Chef Choong Pak Siong } \\
\text { prepares the spaghetti marinara }\end{array}$ \\
\hline 13 & $\begin{array}{l}\text { Your arms and hands. Pumpong } \\
\text { Restaurant }- \text { a place to try out }\end{array}$ & kampung & $\begin{array}{l}\text { delicacies such as ulam (traditional salad), } \\
\text { pucuk paku (fern }\end{array}$ \\
\hline 14 & $\begin{array}{l}\text { as gangster drivers, Indians as drunk } \\
\text { drivers and Malays as typical }\end{array}$ & kampung & $\begin{array}{l}\text { drivers," he said. Revealing that accidents } \\
\text { cost RM6bil a year in }\end{array}$ \\
\hline 15 & $\begin{array}{l}\text { to bring along the serikaya she had made } \\
\text { with specially ordered }\end{array}$ & kampung & $\begin{array}{l}\text { eggs from Malacca. "My maid forgot!" } \\
\text { she said in that exuberant }\end{array}$ \\
\hline 16 & $\begin{array}{l}\text { to take you to kampung Peruang. Located } \\
22 \mathrm{~km} \text { from Benta, the }\end{array}$ & kampung & $\begin{array}{l}\text { evolves around the production of gula } \\
\text { kabung (wild palm sugar). }\end{array}$ \\
\hline 17 & $\begin{array}{l}\text { towards the Muslim Refugees Fund. It } \\
\text { offers a tempting array of }\end{array}$ & kampung & $\begin{array}{l}\text { favourites like sup ekor, ulam with } \\
\text { sambal, sambal udang galah }\end{array}$ \\
\hline 18 & $\begin{array}{l}\text { started this home within my kampung. } \\
\text { We are appreciative that the }\end{array}$ & kampung & $\begin{array}{l}\text { folk here give us so much support. "We } \\
\text { even get invited to kenduri }\end{array}$ \\
\hline 19 & $\begin{array}{l}\text { vacation time! Townees head for the rural } \\
\text { village idylls, the }\end{array}$ & kampung & $\begin{array}{l}\text { folk make an excursion to the bright lights } \\
\text { of the city. Resorts are }\end{array}$ \\
\hline 20 & $\begin{array}{l}\text { were many creative innovations produced } \\
\text { by the locals, including }\end{array}$ & kampung & $\begin{array}{l}\text { folk, that were not patented due to their } \\
\text { ignorance about the matter. }\end{array}$ \\
\hline 21 & $\begin{array}{l}\text { S-76B, Eurocopter AS 350, Dauphin AS } \\
365 \text { and Bell 206. As }\end{array}$ & kampung & $\begin{array}{l}\text { folk, we never celebrated the birthdays of } \\
\text { family members; so mine }\end{array}$ \\
\hline 22 & $\begin{array}{l}\text { the VIPs, corporate figures, MPs and } \\
\text { assemblymen to the ordinary }\end{array}$ & kampung & $\begin{array}{l}\text { folk. Some guests from other states, } \\
\text { mostly Umno members, had }\end{array}$ \\
\hline 23 & $\begin{array}{l}\text { such designs or products when in reality, } \\
\text { it is the innovations of the }\end{array}$ & kampung & $\begin{array}{l}\text { folk." He said this when debating the } \\
\text { Intellectual Property }\end{array}$ \\
\hline 24 & $\begin{array}{l}\text { to see floating obstacles up ahead. For } \\
\text { just a few kupang }(10 \mathrm{sen}) \text {, }\end{array}$ & kampung & $\begin{array}{l}\text { folks (yes, the kampung is right next to } \\
\text { downtown!) can avail }\end{array}$ \\
\hline 25 & ENJOY & kampung & $\begin{array}{l}\text { food in the cool comfort of Toppot Cafe } \\
\text { at Kuala Lumpur }\end{array}$ \\
\hline 26 & are included in the buffet spread to add & kampung & food places a lot of emphasis on ulam and \\
\hline
\end{tabular}




\begin{tabular}{|c|c|c|c|}
\hline 27 & $\begin{array}{l}\text { variety. "Traditional } \\
\text { and his team. The Bistro will be } \\
\text { transformed into a typical }\end{array}$ & kampung & $\begin{array}{l}\text { kerabu. That is why we } \\
\text { for the promotion. The buffet spread } \\
\text { includes a selection of ulam }\end{array}$ \\
\hline 28 & $\begin{array}{l}\text { society runs in Azizul's family. "My } \\
\text { father was the president of our }\end{array}$ & kampung & $\begin{array}{l}\text { gotong-royong. I was brought up in an } \\
\text { environment where we were }\end{array}$ \\
\hline 29 & $\begin{array}{l}\text { and help by housing the soldiers for more } \\
\text { than one month at their }\end{array}$ & kampung & $\begin{array}{l}\text { homes. "My men feel happy for the } \\
\text { children," he added. The }\end{array}$ \\
\hline 30 & $\begin{array}{l}\text { foot, the number of vehicles was a } \\
\text { surprise. The house was a typical }\end{array}$ & kampung & $\begin{array}{l}\text { house but the host had set up zinc tents } \\
\text { and long tables for dining. }\end{array}$ \\
\hline 31 & $\begin{array}{l}\text { residence at Bukit Megawati, Section 7, } \\
\text { Shah Alam, or at his }\end{array}$ & kampung & $\begin{array}{l}\text { house in Sekinchan where he was born. } \\
\text { "He still wears a singlet }\end{array}$ \\
\hline 32 & $\begin{array}{l}\text { include a palm garden with many species, } \\
\text { a lookout tower, a Malay }\end{array}$ & kampung & $\begin{array}{l}\text { house, boat rides and fishing. Four Nile } \\
\text { hippopotami which were }\end{array}$ \\
\hline 33 & $\begin{array}{l}\text { petrol was open, of course, but they } \\
\text { managed to get a quart from a }\end{array}$ & kampung & $\begin{array}{l}\text { house. That got them as far as Balok. I } \\
\text { didn't dress; I just got in }\end{array}$ \\
\hline 34 & $\begin{array}{l}\text { 350cc capacities. Many are still around; } \\
\text { quite a few rotting under }\end{array}$ & kampung & $\begin{array}{l}\text { houses all over the country. Owner } \\
\text { profile, based on the club's }\end{array}$ \\
\hline 35 & $\begin{array}{l}\text { with a gradient of more than } 25 \text { degrees. } \\
\text { "However, longhouses and }\end{array}$ & kampung & $\begin{array}{l}\text { houses in Sarawak are being constructed } \\
\text { without the need of }\end{array}$ \\
\hline 36 & $\begin{array}{l}\text { other insects. Balik Pulau kampung } \\
\text { houses The traditional Malay }\end{array}$ & kampung & $\begin{array}{l}\text { houses of Balik Pulau feature elaborate } \\
\text { carvings, traditional roofs, }\end{array}$ \\
\hline 37 & $\begin{array}{l}\text { colourful butterflies, frogs, scorpions and } \\
\text { other insects. Balik Pulau }\end{array}$ & kampung & $\begin{array}{l}\text { houses The traditional Malay kampung } \\
\text { houses of Balik Pulau }\end{array}$ \\
\hline 38 & $\begin{array}{l}\text { "Undi orang kita," read another Barisan } \\
\text { banner hung at a Malay }\end{array}$ & kampung & $\begin{array}{l}\text { in the constituency of Demak Luat } \\
\text { fringing the city. When the }\end{array}$ \\
\hline 39 & $\begin{array}{l}\text { Bidayuh are reputed to be the best } \\
\text { makers of tuak or rice wine. The }\end{array}$ & kampung & $\begin{array}{l}\text { is divided into two by Sungai Sarawak } \\
\text { Kanan, one of the tributaries }\end{array}$ \\
\hline 40 & $\begin{array}{l}\text { up ahead. For just a few kupang (10 } \\
\text { sen), kampung folks (yes, the }\end{array}$ & kampung & $\begin{array}{l}\text { is right next to downtown!) can avail } \\
\text { themselves of this regular }\end{array}$ \\
\hline 41 & $\begin{array}{l}\text { Zainul Abidin Abdullah has started } \\
\text { visiting district offices and }\end{array}$ & "kampung & chiefs" to promote the scheme. \\
\hline 42 & $\begin{array}{l}\text { director Zainol Abidin Din. Abdul Halil } \\
\text { said the proposed }\end{array}$ & "kampung & $\begin{array}{l}\text { kastam" would be implemented } \\
\text { immediately. Each "kampung }\end{array}$ \\
\hline 43 & $\begin{array}{l}\text { single-storey houses. Three places have } \\
\text { been earmarked for the }\end{array}$ & "kampung & $\begin{array}{l}\text { kastam" project. They are Bukit Gelugor } \\
\text { (100 units), Larkin, Johor }\end{array}$ \\
\hline 44 & $\begin{array}{l}\text { Sat. - The Royal Customs and Excise } \\
\text { Department will develop }\end{array}$ & "kampung & $\begin{array}{l}\text { kastam" (customs villages) on its own } \\
\text { following the failure of the }\end{array}$ \\
\hline 45 & $\begin{array}{l}\text { "kampung kastam" would be } \\
\text { implemented immediately. Each }\end{array}$ & "kampung & $\begin{array}{l}\text { kastam", he said, would consist of at least } \\
\text { one block of four-storey }\end{array}$ \\
\hline 46 & $\begin{array}{l}\text { is certain. The struggle must continue for } \\
\text { the sake of the students. }\end{array}$ & "kampung & $\begin{array}{l}\text { kids don't have ample opportunities to } \\
\text { realise their dream." Thanks }\end{array}$ \\
\hline 47 & $\begin{array}{l}\text { for the purpose. "We have engaged the } \\
\text { private sector to build a }\end{array}$ & kampung & $\begin{array}{l}\text { kastam in Bukit Gelugor, but to no avail. } \\
\text { "The project did not get }\end{array}$ \\
\hline 48 & $\begin{array}{l}\text { proud of the fact that his students have } \\
\text { evolved from self-conscious }\end{array}$ & kampung & $\begin{array}{l}\text { kids into confident, independent and } \\
\text { responsible citizens. Having }\end{array}$ \\
\hline 49 & Rustic scenes of & kampung & $\begin{array}{l}\text { life and fishermen at sea catch one's eye, } \\
\text { evoking a sense of }\end{array}$ \\
\hline 50 & $\begin{array}{l}\text { operations manager Rupert Christie said } \\
\text { visitors liked the laidback }\end{array}$ & kampung & $\begin{array}{l}\text { life within the } 6,000 \text { ha resort area. } \\
\text { "People who visit the resort }\end{array}$ \\
\hline 51 & $\begin{array}{l}\text { arawana, horses, "flowers of fortune", } \\
\text { orchids and scenes of }\end{array}$ & kampung & $\begin{array}{l}\text { life, among others. The special focus at } \\
\text { the exhibition will be the }\end{array}$ \\
\hline 52 & $\begin{array}{l}\text { my parents, my appointment was a } \\
\text { surprise. Once they led a quiet }\end{array}$ & kampung & $\begin{array}{l}\text { lifestyle, now they are the focus of public } \\
\text { attention. My siblings }\end{array}$ \\
\hline 53 & $\begin{array}{l}\text { Malay dishes. I have spent close to } 10 \\
\text { years talking with the }\end{array}$ & kampung & $\begin{array}{l}\text { 'makciks' and other sources to unlock the } \\
\text { secrets of Malay food, }\end{array}$ \\
\hline 54 & $\begin{array}{l}\text { cock? It was a first day cover. They were } \\
\text { featuring stamps ayam }\end{array}$ & kampung & $\begin{array}{l}\text { or something? W: How do you deal with } \\
\text { rude callers? LK }\end{array}$ \\
\hline 55 & $\begin{array}{l}\text { middle-class came into being. Hitherto, } \\
\text { the Malays only evoked the }\end{array}$ & ing & $\begin{array}{l}\text { people and their attitudes. At the top, } \\
\text { there were Sultans and their }\end{array}$ \\
\hline 56 & Every year, he always made it a point to & kampung & people in Morib. I also spent many \\
\hline
\end{tabular}


spend time with the

57 also where the Gen-X urban culture and kampung the traditional values in the

58 facilities in villages, including new kampung villages and traditional Malay

59 boost in the tourism industry has allowed kampung the locals as well as the

60 Malacca. Villagers from Kg Permatang kampung Rawa and the other nearby

61 forests as would be expected, but also kampung what he calls katak

62 But other than these "minor" differences, kampung they're your average

63 owner in their midst. According to the kampung news report, the entire

64 time. Then it was a common sight to see kampung kids roaming around the

65 Lanjut to be specific is a perfect sojourn kampung in a setting of a tranquil

66 fast). This practice is known as pakatan. kampung A group of neighbours in a

67 centre to Pangsoon Dam takes about 45 "kampung" minutes. Small shops and

68 a tea kiosk and a pottery corner. 'kampung' Kampung Seronok, Bayan Lepas A

69 Bidayuh people. Let the guide narrate the kampung's legend and myth of the

70 Kampung Parit Bugis village chief kampung's Mahmud Maarof, 50, said the

71 on MYC's monitoring into several kampung, popular chat rooms such as

72 between urban and rural areas, and kampung, improving facilities in the

73 it shouldn't be the case - even if the kampung, patient is someone from the

74 wooden houses are unmistakably Malay kampung, and if you seek in the

75 figure-types of Datuk Chuah Teng kampung-based Teng, the batik pioneer whose

76 the Central Market, the eatery promises kampung-style dishes in a

77 Jaya, Selangor has lined up an kampung-style extravagant array of citarasa ala

78 SMI Ipoh on Dec 12, 1912, with 39 kampung-style boys who began schooling in a

79 Petaling Street and the Central Market, kampung-style the eatery promises

80 family had lived in a semi-detached kampung-style house that boasted a beautiful

81 most preserved villages. The people still kampung-style live in their traditional

82 Following this, society members were ushered into a Malay

84 heard you did odd jobs, went house to house selling things in the 85 they go to the pondok school, then they kampung.
become the imam in the

86 would hide in the jungle each time kampung. holidays with Opa. When I was

setting come into contact - and inadvertantly clash. Add in a gatal

to ensure the people living in these areas also enjoy a good quality

to prosper, but there is nothing much that can be offered by these

toil in the fields or cast their nets over the ocean for their

(village frogs) - species more common in human settlements rather

(village) folk who live very katak di bawah tempurung (secluded)

was enveloped in a foul smell due to an illegal discharge of

with sores all over their bodies, with rotten teeth and various health

with warm hospitality and services.

would get together to form a pakatan. The move is usually initiated

houses make up the scenery. Those who prefer a bus ride can take

or village which is 'open' to visitors who are free to observe and

history and warriors while the kampung and its friendly residents

Rela patrol unit spotted a motorcycle parked at the house at about 2 .

mamak, veteran, klsex and sexmelayu, there were several nick

new villages and estate schools. Others who followed them were to

she deserves to know what's happening to her health and doctors

you'll meet artisans of various art and craft: batik, silverware,

maidens are so earthy and warm. "Though my art has been linked

ambience, in line with its buffet themed Kampungku. The

buka puasa treats for patrons. The menu is served buffet-style

bungalow at the site of the present school. It grew to become

dishes in a kampung-style ambience, in line with its buffet

garden. They moved into the condominium almost two years ago

homes and leadthe life like their ancestors did almost six

restaurant called The Gulai House. Special guests for the even

dishes are being served at Abdul \& Charlie's Aneka Citarasa

A: I used to cycle and sell ice-cream, tapioca chips and kueh sagu

And that's when the problem starts," said Alwi. In fact, the schools

Since her family owned some land, they 


\begin{tabular}{|c|c|c|c|}
\hline 87 & $\begin{array}{l}\text { Japanese soldiers raided the } \\
\text { and to hide everytime they heard an } \\
\text { aircraft hovering over their }\end{array}$ & kampung. & $\begin{array}{l}\text { were able to plant some } \\
\text { Sometimes in hushed tones, she would } \\
\text { speak about the times when }\end{array}$ \\
\hline 88 & $\begin{array}{l}\text { who go off to spend a weekend at their } \\
\text { grandparents' home in the }\end{array}$ & kampung. & $\begin{array}{l}\text { The children's grandmother offers } \\
\text { wisdom through the age-old }\end{array}$ \\
\hline 89 & $\begin{array}{l}\text { That is the other reason why I started } \\
\text { this home within my }\end{array}$ & kampung. & $\begin{array}{l}\text { We are appreciative that the kampung } \\
\text { folk here give us so much }\end{array}$ \\
\hline 90 & $\begin{array}{l}\text { us? Which State will go first? Can } \\
\text { somebody just buy a whole }\end{array}$ & kampung? & $\begin{array}{l}\text { It's so embarrassing when these banners } \\
\text { are flying nationwide! }\end{array}$ \\
\hline 91 & $\begin{array}{l}\text { of villagers were also facing difficulties } \\
\text { getting in and out of their }\end{array}$ & kampungs & $\begin{array}{l}\text { after the floods as the roads leading to } \\
\text { these areas had been }\end{array}$ \\
\hline 92 & $\begin{array}{l}\text { as the Cradle of Malay Culture. Rustic } \\
\text { settings of picturesque }\end{array}$ & kampungs & $\begin{array}{l}\text { amidst padi fields give insights into a way } \\
\text { of life that has endured }\end{array}$ \\
\hline 93 & $\begin{array}{l}\text { colour and history. "It's like the old } \\
\text { days where people lived in }\end{array}$ & kampungs & $\begin{array}{l}\text { and Chinatown which were colourful, } \\
\text { surprising and untidy too. }\end{array}$ \\
\hline 94 & $\begin{array}{l}\text { parties took the pros and cons of the } \\
\text { Malaysia proposal to the }\end{array}$ & kampungs & $\begin{array}{l}\text { and longhouses. The Malay-Muslim } \\
\text { communities (Malays and }\end{array}$ \\
\hline 95 & $\begin{array}{l}\text { Nasional. In recent months Umno flags } \\
\text { have been hoisted in several }\end{array}$ & kampungs & $\begin{array}{l}\text { and one house in Bako near here had } \\
\text { even banners claiming to be a }\end{array}$ \\
\hline 96 & $\begin{array}{l}\text { including } 17 \text { women, were arrested in } \\
\text { kongsi, shophouses, }\end{array}$ & kampungs & $\begin{array}{l}\text { and rented rooms in Plentong, Masai, } \\
\text { Larkin, Pandan and the city," }\end{array}$ \\
\hline 97 & $\begin{array}{l}\text { Junior League, while a few raw gems } \\
\text { were winched from their cosy }\end{array}$ & kampungs & $\begin{array}{l}\text { and thrown into Lissek's cooking pot } \\
\text { where he added some spice }\end{array}$ \\
\hline 98 & $\begin{array}{l}\text { even though civil servants get the } \\
\text { money, their parents in the }\end{array}$ & kampungs & $\begin{array}{l}\text { and traders will also get more income," } \\
\text { he said. He said Budget }\end{array}$ \\
\hline 99 & $\begin{array}{l}\text { "We want to see significant things } \\
\text { being done in smaller towns and }\end{array}$ & kampungs & $\begin{array}{l}\text { as well. This is a priority," he said when } \\
\text { launching the new tamu }\end{array}$ \\
\hline 100 & $\begin{array}{l}\text { been launched in six States with talks } \\
\text { being given in towns and }\end{array}$ & kampungs & $\begin{array}{l}\text { by various women's groups. "On our } \\
\text { part, we have succeeded in }\end{array}$ \\
\hline 101 & $\begin{array}{l}\text { that there were two plantation headmen } \\
\text { at Sungai Chuan, and their }\end{array}$ & kampungs & $\begin{array}{l}\text { contained an additional } 160 \text { people. They } \\
\text { had already cleared and }\end{array}$ \\
\hline 102 & $\begin{array}{l}\text { generally higher," he said. Mustapa said } \\
\text { nearly every household in }\end{array}$ & kampungs & $\begin{array}{l}\text { had someone working in the civil service } \\
\text { and they depended on this }\end{array}$ \\
\hline 103 & $\begin{array}{l}\text { between Beaufort and Tenom } \\
\text { temporarily. Road links to several }\end{array}$ & kampungs & $\begin{array}{l}\text { have also been cut. In Tenghilan near } \\
\text { Kota Belud, villagers of Kg }\end{array}$ \\
\hline 104 & $\begin{array}{l}\text { frequent tea parties for the poor folk } \\
\text { and enjoyed visiting obscure }\end{array}$ & kampungs & $\begin{array}{l}\text { in Selangor. Every year, he always made } \\
\text { it a point to spend time }\end{array}$ \\
\hline 105 & $\begin{array}{l}\text { in her library in a middle-class enclave } \\
\text { surrounded by Malay }\end{array}$ & kampungs & $\begin{array}{l}\text { in Selayang, Selangor, and she is talking } \\
\text { animatedly about her }\end{array}$ \\
\hline 106 & $\begin{array}{l}\text { four major towns. Good road networks } \\
\text { linking the town to most }\end{array}$ & kampungs & $\begin{array}{l}\text { in the area as well as to Belaga have been } \\
\text { constructed. With the }\end{array}$ \\
\hline 107 & $\begin{array}{l}\text { a landslip at Kampung Rumindahu in } \\
\text { Kiulu cut off links to several }\end{array}$ & kampungs & $\begin{array}{l}\text { in the area while a family living nearby } \\
\text { had been advised to move }\end{array}$ \\
\hline 108 & $\begin{array}{l}\text { to take pictures of the highways, the big } \\
\text { buildings; we went to the }\end{array}$ & kampungs & $\begin{array}{l}\text { instead," relates Peris. Like Chinese } \\
\text { brushworks, it is the }\end{array}$ \\
\hline 109 & $\begin{array}{l}\text { three road collapses and at least three } \\
\text { bridges being damaged near }\end{array}$ & kampungs & $\begin{array}{l}\text { just off the Beaufort-Sipitang road have } \\
\text { been reported. Some } 40\end{array}$ \\
\hline 110 & $\begin{array}{l}\text { claimed were causing environmental } \\
\text { problems. Villagers from six }\end{array}$ & kampungs & $\begin{array}{l}\text { near the area claimed that clear-felling by } \\
\text { a logging company since }\end{array}$ \\
\hline 111 & $\begin{array}{l}\text { park, Eco-park, Skycycle and guided } \\
\text { tours to the traditional Malay }\end{array}$ & kampungs & $\begin{array}{l}\text { of Kuala Setapang and Kampung } \\
\text { Selamat. The guided tour package }\end{array}$ \\
\hline 112 & $\begin{array}{l}\text { and PAS as well as Umno flags have } \\
\text { been flying in several }\end{array}$ & kampungs & $\begin{array}{l}\text { since last general election to garner } \\
\text { Malay and Muslim support. }\end{array}$ \\
\hline 113 & $\begin{array}{l}\text { purposes," he said. Earlier this week, } \\
\text { villagers from six }\end{array}$ & kampungs & $\begin{array}{l}\text {-Tangao, Mempait, Lagkau, } \\
\text { Silimpangan, Randagong Lama and }\end{array}$ \\
\hline 114 & $\begin{array}{l}\text { Pas was and is shrewd. While it tells } \\
\text { the Malays in towns and }\end{array}$ & kampung & $\begin{array}{l}\text { that their special rights and privileges } \\
\text { have diminished under }\end{array}$ \\
\hline 11 & $\begin{array}{l}\text { bird lovers, visitors and tourists now } \\
\text { converge on the tranquil }\end{array}$ & $\mathrm{k}$ & $\begin{array}{l}\text { to observe the many birds which fly } \\
\text { thousands of kilometres from }\end{array}$ \\
\hline 116 & just round the corner and many of you & gs & to spend it with your loved ones. In the \\
\hline
\end{tabular}




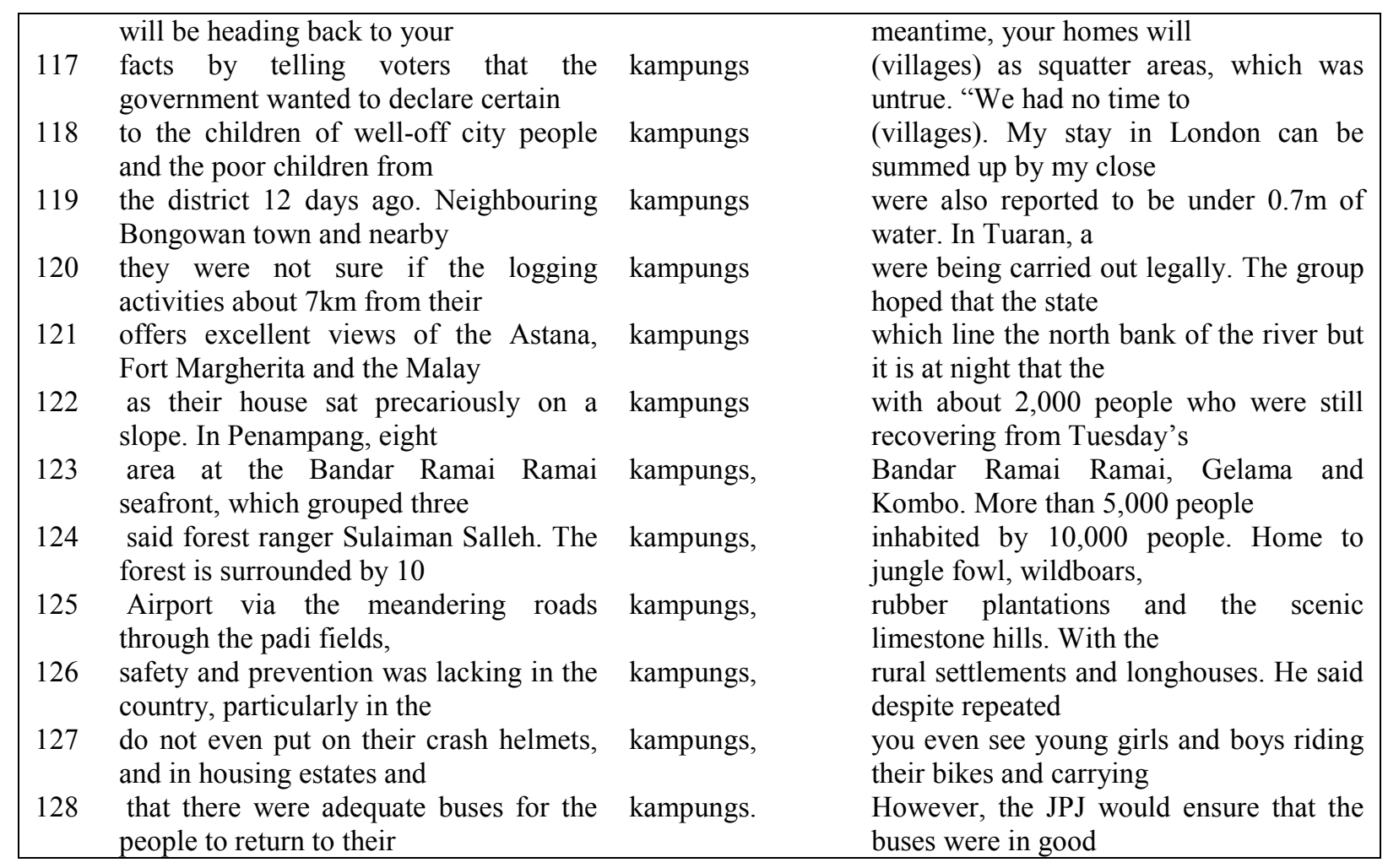

\section{Figure 3. Edited concordance display of kampung* from the MEN Corpus}

From these concordance lines, it was concluded that kampung is typically used as a noun to denote "a small village" (lines 2, 3, 6, 16). In addition to this, it is often used as an attributive adjective to refer to characteristics associated with a (Malay) village. For instance, kampung house means "traditional (Malay) house - usually on stilts, made of wood, etc." (lines 30 to 37) while kampung chicken is a "local breed of chicken usually bred in the backyard by rural folks" (lines 8 to 10). The word kampung is used to modify the noun (house or chicken) and as befitting of a simple noun phrase in English, the adjective precedes the noun. These two constructions are modelled after existing Malay features - rumah kampung and ayam kampung - and are therefore regarded as compound blends. Besides these attributive uses, we also see kampung used as the head of certain nominal phrases. For example, the compound blend Malay kampung (modelled after kampung Melayu) can refer to anything from a cluster of traditional Malay houses to a small town of a few thousand mostly ethnically Malay people (lines 39, 58, 105, 111 and 121). The noun kampung is typically treated as a count noun in ME. It takes the plural $-s$ morpheme (lines 91 to 128), and in its singular form it takes the indefinite article $a$ (lines 3, 38, 66). It can be modified by numerals (lines 113, 122 to 124) and the quantifier several (line 95, 103 and 107).

It must be emphasised that there are exceptions to these patterns, and so we do see, for example, the occurrence of an uninflected kampung preceded by a numeral (line 5). We also see instances where kampung implies 'Malayness' (for example, in line 17, what constitutes kampung favourites is clearly rural Malay cuisine) and instances where this association is not as overt (the occurrence of Malay kampung must surely imply that the sense of 'Malayness' does not have to be built into the meaning of kampung). On the whole, however, a great deal of systematicity and stability can be observed in the ways that the loanword kampung and its corresponding compound blends are used in ME, and it is this that makes these features such ideal candidates for codification. The dictionary entry in Figure 4 provides a summary of the 
semantic and morphosyntactic information discussed above. Citations sourced from the MEN Corpus are included to illustrate the use of these features where necessary.

kampung $n$. Pl. -s. [Malay] A small village.

Attrib.: kampung house [Malay rumah kampung] traditional (Malay) house on stilts, usually made of wood and with a thatched roof; kampung chicken [Malay ayam kampung] local breed of chicken usually raised in the backyard by rural folk using traditional methods and therefore regarded as having better meat quality.

2001 The Star 22 Sept. According to Sundram, British bikes were extensively used in the estates by management staff to get around. In addition, the police, army and postal services owned many too, especially BSAs of $250 \mathrm{cc}$ and $350 \mathrm{cc}$ capacities. Many are still around; quite a few rotting under kampung houses all over the country. 2001 New Straits Times 26 Aug. TCRS offers customers a choice of ordinary chicken or kampung chicken with a slight difference in prices.

Comb.: Malay kampung [Malay kampung Melayu] a Malay village.

2001 New Straits Times 11 Sept. We are sitting in her library in a middle-class enclave surrounded by Malay kampungs in Selayang, Selangor, and she is talking animatedly about her latest project: implementing a community transport service in the Klang Valley for those unable to use, or who have difficulty in using, public transport.

Figure 4. Entry for kampung

As can be seen, this process of codification involved more than putting together words, definitions and citations. It was a labour-intensive process whereby hundreds of distinctive features were examined in context for evidence that their presence in the MEN Corpus is not arbitrary, and is in fact characterised by systematicity and stability. I was therefore not merely interested in the fact that some lexical or semantic or morphosyntactic change or integration had been identified. I was more concerned with finding out whether this change recurred (meaning that it is stable) and whether there appeared to be a motive behind the change (meaning that if the same motive occurs in other contexts, a similar change can be expected). So in coming to the conclusion that the loanword kampung is regarded as a count noun in $\mathrm{ME}$, I had noted that there are recurring examples of kampungs being used to denote "small villages," and that kampung takes the indefinite article $a$ as well as a few numerals and the quantifier several. Since kampung is semantically similar to village, it is logical that ME users should apply the property of countability to this Malay loanword. ME users are presumably motivated, not only by the need to make this loanword behave more like an English word, but also by the need to make it more versatile.

The appendix provides a better demonstration of the potential for codifying the lexicon of ME. It is obvious that there is a need for more research which analyses the entire range of contact-induced linguistic changes and takes into account the whole spectrum of source languages that have influenced ME. This is crucial if the vocabulary of ME is to be codified. The importance of codifying the lexicon of new varieties of English such as ME is best represented using Bolton and Butler's [2004: 92] summation of Quirk's [1990] opinion:

[...] it is only when a world variety of English is supported by codification (chiefly expressed through national dictionaries) that one can make the claim that a variety is 'institutionalised.'

The present attempt at codification, though preliminary, opens doors to the possibility of utilising an endonormative model for pedagogical purposes in the context of Malaysia. As it is now widely-accepted that "the advantages of choosing a local model in outer-circle countries in which the local variety has already gained widespread social acceptance outweigh 
the advantages of choosing a native speaker model" (Kirkpatrick [2007: 193]), more effort should be put into codifying and therefore legitimising $\mathrm{ME}$ and other new varieties of English.

\section{Motivations for borrowing}

The non-arbitrariness of lexical borrowing in ME is most apparent when we reflect on the factors that motivate ME users to use Malay words and phrases in their variety of English.

The vast majority of borrowed features in ME derive from the need to refer to local objects and cultural constructs for which there are no pre-existing English words. Most of the items listed under the semantic fields of food, social and recreational activities, clothing and folk religion (see Table 1) in particular, do not have equivalents in English. The prolific borrowing of such Malay terms can be explained in terms of the retention of Malay culture and tradition by many Malaysians regardless of ethnicity. Malay dishes and indigenous foodstuffs (e.g., asam pedas, cincalok and rendang) are ubiquitous elements of the local gastronomic scene; traditional social and recreational activities (e.g., silat, congkak, gasing and wau are still enjoyed by various segments of the society despite the pervasiveness of western games and sports; traditional attire (e.g., baju kurung and baju Melayu), accessories (e.g., kerongsang and songkok) and textiles (e.g., batik and songket) co-exist with jeans, Tshirts, dresses, suits and jackets; and spirits (e.g., hantu, jembalang and pontianak) and traditional healers (e.g., bomoh, dukun and pawang) continue to be important parts of the belief systems of the society. The continuing relevance of indigenous objects and cultural concepts means that there is an ongoing need to talk about them, especially within the everyday domains of family, friendship and transactions. ME users who find the need to refer to them naturally make use of the original Malay words because they are widely understood. Furthermore, as Weinreich [1953: 57] puts it, "lexical borrowing of this type can be described as a result of the fact that using ready-made designations is more economical than describing things afresh. Few users of language are poets."

Sometimes, ME users adopt local words in order to make finer distinctions of meaning. For instance, gasing "giant top" and wau "large kite" are used to distinguish these giant toys from their smaller cousins - the top "small conical plaything tapering to a steel point on which it can be made to spin" and the kite "light framework covered with cloth, plastic or paper, designed to be flown in the wind at the end of a long string" respectively. Menteri Besar "chief minister of any of the Malay states - Johor, Perlis, Perak, Pahang, Kedah, Selangor, Negeri Sembilan, Terengganu and Kelantan" is differentiated from Chief Minister "chief minister of Penang, Melaka, Sabah and Sarawak." A pelamin is not just any ordinary dais but one which is used during a Malay wedding ceremony. Other Malay borrowings thus motivated are: baju kebaya, baju Kedah and baju kurung (diverse styles of the traditional attire worn by Malay women); bomoh, dukun and pawang (different kinds of traditional healers); and hantu, jembalang, orang minyak and pontianak (various forms of evil spirits).

Certain Malay words also convey specific undertones that are difficult to replicate using existing English word. These words are prime candidates for borrowing. The expressions, gatal "flirtatious," ulu "back-country," jaguh kampung "an athlete who can only win on the home turf," and tidak apa or tidak apa attitude "lackadaisical" are a few examples of such features. To illustrate this point, we can examine the borrowing of tidak apa. The root of tidak apa or tidak apa attitude is the conciliatory Malay expression tidak mengapa (formal) or tidak/tak apa (colloquial). Both expressions can be loosely translated as "it doesn't matter." In Malay, these expressions are used in a variety of situations. Among other things, they are used as a rejoinder to an apology or a remark intended to pacify. For instance, if a builder hired by 
a house-owner is a little late in completing his work, he might apologise to the house-owner, who in turn might respond by saying tak apa (sometimes sincerely, but often in spite of feeling a little put out). If the house-owner, annoyed by the delay, grumbles to his wife that the builder is unreliable, she might attempt to pacify him by saying tak apa. In the second instance of tak apa, the wife might be advising her husband not to get upset over the issue, that it is just a slight delay, and that it does not matter. The use of tak apa above might not sound very different from the use of "it doesn't matter" in English, except that in Malay, the meaning of tidak apa has been extended to include a disparaging label for someone who is highly tolerant of procrastination and inefficiency, someone who says tak apa to everything, in short, someone who is habitually lackadaisical or apathetic. The ME terms tidak apa and tidak apa attitude convey an undertone of derision (sometimes self-derision) which is probably more marked than in either "lackadaisical" or "apathetic."

There are instances when a Malay word is borrowed despite the fact that the referent of this word is already adequately represented in the English language. In such cases, the motivation for adopting the Malay word is less overt, and must be studied with a stronger emphasis on the sociolinguistic perspective.

Certain Malay borrowings, especially those listed under the semantic field of government, administration and the monarchy, appear to be motivated by nationalism. The use of loanwords like Dewan Negara "Senate," Dewan Rakyat "House of Representatives," Datuk Bandar "mayor," Menteri Besar "Chief Minister," and wakil rakyat "representative" not only emphasises the singularity of the Malaysian system of government, but also creates an illusion of distance from the system put in place by the former British colonial government. The incorporation of these terms into ME highlights the status of the national language and its role as the language of government and administration of Malaysia.

Another class of borrowed features is associated with social protocol, in particular with proper terms of address that one should use when referring to the elite of society. The Malaysian head of state and his consort are generally referred to as the Yang di-Pertuan Agong and the Raja Permaisuri Agong. The hereditary rulers of the nine Malay states are known as Sultans (or Raja and Yang di-Pertuan Besar in Perlis and Negeri Sembilan respectively) while the appointed governors of Melaka, Penang, Sabah and Sarawak are known as the Yang di-Pertua Neg(e)ri. Besides royal titles, there are also several conferred titles that are used in ME. Some of the more commonly-used titles are Datuk, Datin, Datuk Seri, Datin Seri, Tan Sri and Puan Sri (see the lexical set of conferred titles under the semantic field of people and titles in Table 1). Therefore, although we might see the current Prime Minister of Malaysia referred to by the foreign media as (His Excellency) Mr Abdullah Ahmad Badawi, in Malaysian newspapers he is often referred to, at least in the initial reference, by his designated title Datuk Seri Abdullah Ahmad Badawi. In addition to the titles for the elite, ME has also borrowed several terms of respect as well as some Islamic titles. The informal terms of respect, Pakcik and Makcik (see the lexical set of terms of respect under the semantic field of people and titles in Table 1), are sometimes used in reference to middle-aged Malay males and females respectively, while the Islamic titles Haji and Hajjah/Hajah (see the lexical set of titles under the semantic field of Islam in Table 1) often prefix the names of Muslim men and women who have performed the Haj. The incorporation of these Malay titles into the lexicon of ME allows ME users to maintain the appropriate modicum of decorum expected by society.

The borrowing of Islamic terms into ME, either directly from Malay or from Arabic through Malay, suggests yet another motivation - one related to the assertion of the user's Islamic identity. Islam is the official religion of the country, and the religion professed by the Malays who form the largest ethnic group. The relevance of Islam to the Muslim community in general, and to Muslims who are bilingual in English in particular, has given rise to the 
need to incorporate a whole range of Islamic terms (refer to the semantic field of Islam in Table 1) into ME. It can of course be argued that for the most part, these features are borrowed because there are no pre-existing English words that can adequately describe the events, practices and principles that are so important to the Muslim community. There are however certain Islamic expressions (e.g., Alhamdulillah, Insyaallah and God willing) that are used by Muslims when speaking in English to emphasise their religious affiliation. This is especially important within the socio-political dynamics of Malaysia, where there exist proMalay economic policies, and there is a close association between Islam and the ruling elite.

We can thus see from the above that lexical borrowing in ME is not a random process of reproducing Malay words in English-language discourse. It is motivated by very specific linguistic and social needs of the multilingual speech community that uses English to communicate aspects of their sociocultural milieu. As these needs are consistent and ongoing, they induce predictable contact-induced linguistic changes in ME, some of which have been examined in this paper.

\section{Conclusion}

Speakers of other varieties of English are often confounded by the presence, in ME, of words and phrases from Malay, Hokkien, Cantonese, Mandarin, Tamil, Hindi, Iban, Kadazan and a myriad of other local languages. What must appear like wholesale transfer of lexical items from one language to another is in reality a highly-structured, hugely-complex phenomenon. This paper is a corpus-based examination of aspects of this contact phenomenon.

In her attempt at formally distinguishing code-switching from lexical borrowing, Poplack [2001: 3] makes the following conclusion about the latter:

Despite etymological identity with the donor language, established loanwords assume the morphological, syntactic, and often, phonological, identity of the recipient language. They tend to be recurrent in the speech of the individual and widespread across the community.

The veracity of her observation is reflected in the data - not just the loanwords, but also the compound blends and loan translations - discussed in this paper. ${ }^{14}$ We have seen how numerous Malay borrowings can be made more 'English-like' via the means morphosyntactic (and to a lesser extent, phonological) processes. The pervasiveness of Malay borrowings is reflected in the spread of these features across diverse semantic fields. It is clear that $\mathrm{ME}$ users incorporate these features in their variety of English because they have a need to enrich its lexicon. Because ME is maintained intranationally, it has to have the capacity to express not just functionally but creatively as well - the sociocultural constructs that are relevant to the vast majority of Malaysians, irrespective of ethnic backgrounds.

The presence of a "critical mass" (Myers-Scotton [2002: 238]) of English- and Malayspeaking bilinguals in Malaysia, and the continuing relevance of Malay culture and tradition mean that once initiated, borrowings have ample opportunity to be transmitted to other members of the community. Many of the features we have seen started out as innovations but went on to become permanent additions to the ME vocabulary precisely because they fulfil

\footnotetext{
${ }^{14}$ See Bakaran [2005: 37-43] for more extreme forms of morphological adaptations which tend to be restricted to informal or colloquial ME.
} 
specific linguistic and social needs of society. Once these features enter the lexicon of ME, they are generally acquired along with core English words. The transmission, hence, continues.

That we have been able to take a large body of authentic texts and reduce it to specific patterns of contact-induced linguistic changes is largely attributable to the corpus-based approach. The fact that the linguistic outcomes of lexical borrowing are on the whole systematic and stable means that there is great potential for the codification of the lexicon of ME. As features borrowed from Malay form only a component of possible contact-induced changes, more research has to be done in order to assess the feasibility of codifying other types of linguistic changes in ME.

\section{References}

A Malay-English Dictionary (Romanised), R. J. Wilkinson, London, Macmillan, 1959.

ARFAH Buang, Semantic modifications of Malay loanwords in Singapore Colloquial English, Unpublished B.A. dissertation, National University of Singapore, 1998.

BASKARAN Loga Mahesan, "The "New Englishes"”, paper presented at the First Hong Kong International Conference on Sociolinguistics, The University of Hong Kong, 1988.

---. A Malaysian English Primer: Aspects of Malaysian English Features, Kuala Lumpur, University of Malaya Press, 2005.

Dwibahasa Kamus Delta (Edisi KBSM), Lufti Abas \& Awang Sariyan (Comps.), Petaling Jaya, Pustaka Delta Pelajaran, 1993.

HAUGen Einar, "The analysis of linguistic borrowing", Language, Vol. 26, 1950: 210-231.

Hobson-Jobson: A Glossary of Colloquial Anglo-Indian Words and Phrases, and of Kindred Terms, Etymological, Historical, Geographical and Discursive, in Yule Henry \& Burnell A. C., London, John Murray, 1903 [1984 Reprint].

Hunston Susan \& GiLl Francis, Pattern Grammar: A Corpus-driven Approach to the Lexical Grammar of English, Amsterdam/Philadelphia, John Benjamins, 2000.

Kamus Dewan Edisi Ketiga, Hajah Noresah bt. Baharom, Rusli Abdul Ghani, Mohd. Nor bin Abd. Ghani, Ibrahim bin Ahmad, Aziah bt. Tajudin, Salmah bt. Jabbar, Mariam bt. Mahmud, Diarani bt. Mat Adam \& Rahamah bt. Othman (Eds.), Kuala Lumpur, Dewan Bahasa dan Pustaka, 2000.

Kamus Lanjutan Bahasa Malaysia-Bahasa Inggeris, Abd. Aziz Rahman (Comp.), Petaling Jaya, Federal Publications, 2003.

Kamus Melayu Global, Hasan Hamzah (Comp.), Shah Alam, Piramid Perdana, 1997.

KIRKPATRICK Andy, World Englishes: Implications for International Communication and English Language Teaching, Cambridge, Cambridge University Press, 2007.

LOWENBERG Peter H., English in the Malay Archipelago: Nativization and its functions in a sociolinguistic area, Unpublished Ph.D. dissertation, University of Illinois, 1984.

---. "Sociolinguistic context and second language acquisition: Acculturation and creativity in Malaysian English", World Englishes, Vol. 5(1), 1986: 71-83.

---. "The marking of ethnicity in Malaysian English literature: Nativization and its functions", World Englishes, Vol. 11(2/3), 1992: 251-258.

---. "English as a "neutral" language: The case of Malaysia", paper presented at the Seventh IAWE Conference, 2000.

MCMaноn April M. S., Understanding Language Change, Cambridge, Cambridge University Press, 1994.

Mini-Dictionaries of Southeast Asian Englishes, Lawrence JoHnSON (Ed.), Singapore, SEAMEO Regional Language Centre, 1984. 
MoraIs Elaine, "Lectal varieties of Malaysian English", in OoI Vincent B. Y. (Ed.) Evolving Identities: The English Language in Singapore and Malaysia, Singapore, Times Academic Press, 2001: 33-52.

Myers-SCOTton Carol, Contact Linguistics: Bilingual Encounters and Grammatical Outcomes, Oxford, Oxford University Press, 2002.

Oxford English Dictionary, 2nd Edition, Simpson J. A. \& WeInER E. S. C. (Eds.), Oxford, Clarendon Press, 1989. OED Online, Oxford University Press, The University of Hong Kong Libraries. Available from <http://dictionary.oed.com/entrance.dtl $>$.

PoPlaCK Shana, "Code-switching (linguistic)", University of Ottawa, Department of Linguistics website, 2003. Available from <http://aix1.uottawa.ca/ sociolx/CS.pdf $>$.

QUIRK Randolph, "Language varieties and standard language", English Today, Vol. 21, 1990: 3-21, quoted in Kingsley Bolton \& Susan Butler, "Dictionaries and the stratification of vocabulary: Towards a new lexicography for Philippine English", World Englishes, Vol. 23(1), 2004: 91-112.

REID Anthony, Southeast Asia in the Age of Commerce, 1450-1680, Volume 1: The Lands below the Winds, New Haven, Yale University Press, 1988.

SCHNEIDER Edgar W., "The dynamics of new Englishes: From identity construction to dialect birth", Language, Vol. 79(2), 2003a: 233-281.

---. "Evolutionary patterns of new Englishes and the special case of Malaysian English", Asian Englishes, Vol. 6(2), 2003b: 44-63.

TAN Peter K. W., "Melaka or Malacca; Kallang or Care-Lang': Lexical innovation and nativisation in Malaysian and Singaporean English", in OOI Vincent B. Y. (Ed.) Evolving Identities: The English Language in Singapore and Malaysia, Singapore, Times Academic Press, 2001: 140-167.

TAN Siew Imm, Languages in contact: A corpus-based study of Malaysian Newspaper English, Unpublished Ph.D. dissertation, University of Hong Kong, 2006.

---. "Lexical borrowing in Malaysian English: Influences of Chinese", paper presented at IVACS 2008, Limerick, 2008.

Thomason Sarah Grey, Language Contact: An Introduction, Washington, D.C., Georgetown University Press, 2001.

Thomason Sarah Grey \& KaUfMan Terrence, Language Contact, Creolization, and Genetic Linguistics, Berkeley, University of California Press, 1988.

WeInReICH Uriel, Languages in Contact: Findings and Problems, The Hague, Mouton, 1953.

WINFORD Donald, An Introduction to Contact Linguistics, Oxford, Blackwell, 2003. 


\section{Appendix: Malay borrowings in Malaysian English}

adat $n$. [Malay] 1 Traditional practices and customs of a particular group. 2 Customary law and dispute resolution practices.

12001 New Straits Times 26 Aug. "We have lost our identity and sense of belonging when it comes to adat (customs) for the Malays and the same applies to the Chinese, Indians and Eurasians here." 22001 New Straits Times 18 Aug. Customs or adat are not only peculiar to the Malay Muslims, but also in other nations. Adat, in the Middle East, represents the unwritten customary laws and practices that have the force of social laws and the syariah. As long as the customs do not contradict the syariah, it is acceptable.

Alhamdulillah int. Also alhamdullilah, Alhamdullillah. [Malay, orig. Arabic] Praise be to Allah, an interjection that expresses gratitude.

2001 New Straits Times 16 Aug. The 33-year-old mother of 14-month-old Mohd Aiman Armin, said: "I had a terrible flu. Alhamdulillah, it didn't affect my voice that much during the show."

asam pedas $n$. [Malay] A sour and spicy soup.

baba $n$. \& a. [Malay] A $n$. Pl. same, -s. 1 The Straits Chinese community. 2 The men folk of the Straits Chinese community. B a. Of language, culture, etc.: pertaining to the Straits Chinese community.

A 12001 The Star 1 Nov. The Penang Babas speak the Hokkien dialect incorporating Malay words (the Babas of Malacca and Singapore - the other two cities that comprised the Straits Settlements - speak a type of Creole Malay with Hokkien words). B 2001 The Star 1 Nov. Clubs such as the Chinese Amateur Dramatic Association were not only famous for promoting Baba bangsawan in the 1920s and 1930s but also for presenting their own plays which centred around the stereotypical Baba household in which rich husbands squandered money, stepmothers were strict and mothers-in-law ill-treated their daughters-in-law.

baju Kedah $n$. [Malay] A short blouse with three-quarter length sleeves that is thought to have originated in Kedah. Also a suit comprising the blouse and a long skirt.

2001 New Straits Times 24 Nov. Key pieces in the collection include the classical baju kurung and elegant baju Kedah as well as the more contemporary curvy baju kebaya.

baju kurung $n$. [Malay] A loose knee-length blouse with sleeves that end at the wrists, typically worn by Malay women. Also a suit comprising such a blouse and an ankle-length skirt with folds on the left side.

2001 The Star 6 Sept. Sri Lumandeng, who was clad in a green baju kurung, looked calm throughout the proceedings yesterday and nodded her head as the court interpreter read out the facts of the case.

baju Melayu $n$. [Malay] A long-sleeve shirt with either a round neckline or a Mandarin collar that is worn by Malay men. Also a suit comprising such a shirt and a loose pair of pants.

2001 The Star 14 Oct. Clad in the same white baju melayu that he wore on his wedding day, Mohd Sufian said he regretted what had happened.

balik kampung $v$. [Malay] To visit the (usually rural) home of one's parents, in-laws, siblings or close relatives, during long weekends, festive seasons, etc.

2001 New Straits Times 20 Aug. He would keep repeating the same story everytime we balik kampung. We used to joke among us that he sounded like a broken record.

batik $n$. Also batik cloth. [Malay kain batik] Traditional Southeast Asian wax-resist dyed textile.

2001 The Star 30 Sept. With this encouragement, she started making and selling her batik from a small hut 13 years ago. 2001 New Straits Times 31 Oct. I usually buy scarfs (sic.), batik cloth, clothes for my grandchildren, etc. 
Attrib.: batik art [Malay seni batik] the art of drawing and painting using the wax-resist batik method; batik painter [Malay pelukis batik] an artist who paints on fabric employing techniques and tools used for making batik; batik painting [Malay lukisan batik] the art of painting on fabric employing techniques and tools used for making batik.

2001 New Straits Times 29 Oct. "I spent time observing a commercial batik painter so as to learn how to paint batik. However, when I later tried it out myself, nothing worked," said this renowned batik artist.

bawal hitam $n$. [Malay] A marine fish (Parastromateus niger). Also called black pomfret.

2001 The Star 5 Dec. Its chairman Senator Zainal Rampak had said that there were drastic increase in the prices of essential items like chicken, chicken eggs, coconut, cooking oil, prawns, potatoes, long beans, kangkung, cabbage, red chillies, ikan kembung, tenggiri, bawal putih, bawal hitam, cencaru, ikan merah, local beef, imported beef and mutton.

bawal putih $n$. [Malay] A marine fish (Pampus argenteus). Also called white pomfret.

belacan $n$. [Malay, orig. Minangkabau Malay] Dried shrimp paste.

Comb.: sambal belacan a condiment of blended chillies and belacan.

2001 The Star 20 Oct. Finally, cuttlefish strips are added for the flavour and slight crunch. It is served with sambal belacan and green leaf lettuce.

bersanding ceremony $n$. [Malay majlis persandingan] A Malay wedding ceremony where the bride and the groom sit side by side on a dais awaiting the blessings of the guests.

2001 New Straits Times 2 Nov. The pelamin is an integral part of the Malay wedding ceremony. It is a decorated platform on which newlyweds sit for the bersanding ceremony.

bomoh $n$. Pl. -s. [Malay] A shaman and traditional healer of Malay culture.

2001 New Straits Times 24 Aug. A bomoh from Sabak Bernam, Selangor, claims he has caught what he believes is a langsuir or vampire near a cotton tree two days ago.

briyani rice (tautology) $n$. Also nasi briyani. [Malay, orig. Hindustani biryani] An Indian meat and rice dish.

2001 New Straits Times 7 Sept. The buffet line is filled with assorted Malaysian cuisine, from kurma chicken to spicy lamb, tender beef curry, steamed fish and briyani rice. 2001 New Straits Times 28 Nov. The hampers comprised rice and packets of seasoning for nasi briyani, nasi tomato and chicken.

bubur $n$. [Malay] Porridge or gruel made from rice, beans, lentils or other grains; may be sweet or savoury.

2001 New Straits Times 3 Oct. Although found in other States like Terengganu, Perak or Malacca, locals insist Benta's gula kabung is the best in quality and taste. It enhances the flavour of bubur, local kuih or cendol, they say.

Comb.: bubur cha cha porridge made by boiling pieces of yam, sweet potato, etc. in a broth of coconut milk and sugar; bubur kacang gruel made of various types of beans; bubur lambok/lambuk savoury porridge with meat and spices, traditionally served during the month of Ramadan; bubur pulut hitam sweet porridge made of black glutinous rice.

budu $n$. [Malay, orig. Kelantan Malay] A condiment made by pickling anchovies in brine; popular in the east coast states of Peninsular Malaysia.

2001 New Straits Times 22 Nov. Among the fare served for the hotel's Ramadan buffet dinner are various types of kerabu, ulam-ulaman, sambal belacan, budu and tempoyak.

buka puasa $n$. Also berbuka puasa. [Malay] The breaking of fast: during the month of Ramadan, Muslims fast during the day and break the fast at dusk. 
2001 New Straits Times 24 Nov. If you are not one of those "busy bees" who only have time to grab a murtabak or kuih for berbuka puasa, then stay tuned. Starting today, this page will provide some interesting recipes, both sweet and savoury, Asian and Western, for the aspiring chef.

bumiputera $n$. \& $a$. Also bumiputra. [Malay, orig. Sanskrit bumi earth + putra son] A $n$. Pl. -s. A category created by the Malaysian state to designate those citizens it considers indigenous to Malaysia. B $a$. Of or pertaining to the bumiputeras.

A 2001 The Star 24 Sept. According to the latest electoral roll, Kidurong has 22,001 registered voters, with $51.3 \%$ Chinese and $48.7 \%$ bumiputras (70\% Ibans and 30\% Malays). B 2001 The Star 20 Oct. Amin said he was confident that the budget measures would go a long way towards assisting bumiputra businessmen, especially the medium- and small-scale businessmen now trying to cope with the challenges of globalisation.

non-bumiputera/non-bumiputra a citizen who is considered non-indigenous to Malaysia, usually of Chinese or Indian ethnicity.

Comb.: Muslim bumiputera/Muslim bumiputra a bumiputra of the Muslim faith, usually a Malay or a person belonging to one of the many indigenous tribes of Malaysia; non-Muslim bumiputera/non-Muslim bumiputra a bumiputra who is not a Muslim, usually of Christian or traditional faith.

2001 The Star 3 Aug. At the conclusion of the Upko congress on Wednesday, the party's 315 delegates adopted a resolution asking the state to adopt a 4:4:2 formula in all appointments and promotions in the civil service. This meant that for every 10 civil servants hired or promoted, four should be Muslim bumiputras, another four be non-Muslim bumiputras and two be nonbumiputras.

bunga kantan $n$. [Malay] The pink bud of a ginger plant (Etlingera elatior) that is used to flavour many Malay dishes.

bunga manggar $n$. [Malay] A palm-like structure comprising a pole and plumes of glittery tinsels that it used to decorate the venue during a wedding.

2001 New Straits Times 20 Aug. Besides the beat of the kompang and the glittering bunga manggar, no traditional Malay wedding is complete without a silat performance.

bunga telur $n$. [Malay bunga flower + telur egg] A gift of a boiled egg tied to a paper flower that is given to the guests at Malay weddings.

2001 New Straits Times 17 Sept. As the big day approaches, the neighbours congregate at the house to help make bunga telur, set up the wedding dais and build the balai.

ciku $n$. [Malay] An oval fruit about the size of a large kiwifruit with pale brown thin skin and yellowish, sweet flesh.

2001 New Straits Times 14 Aug. Ciku is a sweet-smelling brown coloured fruit, popular in Asean countries such as Thailand, Vietnam, Indonesia and Malaysia.

cincalok $n$. [Malay] A relish made from small shrimps.

2001 New Straits Times 10 Aug. For the main course, chef Chew recommends the special deepfried chicken, which was marinated with cincalok.

congkak $n$. [Malay] A traditional Malay game played by moving counters from one base to another on a boat-shaped board.

2001 New Straits Times 30 Aug. Traditional games such as sepak raga bulatan and congkak were also held.

dadah $n$. [Malay] A generic name for chemical substances, such as narcotics or hallucinogens, that affect the central nervous system. 
2001 New Straits Times 24 Aug. He said initial investigation showed that the man could have been involved in a spate of armed robberies, motorcycle thefts, tampering of motorcycle chassis numbers, and peddling dadah and pornographic VCDs.

dalang $n$. [Malay] The puppet-master of the wayang kulit or the shadow play.

2001 New Straits Times 23 Oct. I'm a writer; worse, I'm a poet. I'm a dalang, I learn Jawi, and half the time I live in Kelantan. For most parents, it'd be bizarre!

Datin $n$. [Malay] 1 A title reserved for the wife of a man who has been awarded the title of Datuk. 2 The wife of a man who has been awarded the title of Datuk.

12002 The Star 30 Jan. Dr Jeffrey was represented by Datin Marina Tiu ... 22001 The Star 24 Sept. An odd-job labourer, arrested on suspicion of murdering a Datin last year, told a Sessions Court yesterday he admitted to police that he received stolen jewellery after they started beating him.

Datin Seri $n$. [Malay] The title reserved for the wife of a person who has been awarded the title of Datuk Seri.

2001 The Star 23 Dec. Also present were the Tunku Mahkota Tunku Ibrahim Ismail, his consort Raja Zarith Sofiah Sultan Idris Shah, members of the Johor royal family, Deputy Prime Minister Datuk Seri Abdullah Ahmad Badawi and his wife Datin Seri Endon Mahmood.

Datuk $n$. Pl. -s. [Malay] 1 An honorary and non-hereditary title awarded either by the federal government or the state rulers. 2 A person who has been awarded the title of Datuk.

12001 The Star 21 Nov. The Malaysian embassy in the Republic of Ireland will open soon with Datuk Ali Abdullah appointed as its first ambassador. 22001 The Star 27 Nov. The Datuk, she claimed, had told her that the police would not dare take action on any report lodged against him and his family members.

Datukship $n$. the state of having been awarded the title of Datuk.

2001 New Straits Times 3 Sept. A casual perusal of the lists reveal that the Datukship recipients range from the royals, party stalwarts, exco members, civil servants, towkays and corporate figures, police and military personnel, entertainers and even unheard-of foreign dignitaries.

Datuk Bandar $n$. [Malay]. A mayor.

2001 New Straits Times 20 Nov. The ceremony was officiated by Kuala Lumpur Datuk Bandar Tan Sri Kamaruzzaman Shariff.

Datuk Seri $n$. [Malay] A honorary title awarded by the state rulers of Malaysia.

2002 The Star 2 Jan. Puteri Umno pro-tem chief Azalina Othman Said said issues associated with Datuk Seri Anwar Ibrahim have become stale and would not influence the Indera Kayangan by-election.

daun kesum $n$. [Malay] A pungent herb (Polygonum hydropiper) with long pointed green leaves tinged with purple.

daun mambu $n$. [Malay] A bitter herb that is often used to treat measles and chicken pox.

2001 The Star 14 Oct. Neem grows well in Malaysia and is common to all the races. The Malays call it daun mambu, while the Chinese and Indians call it chin sou chin and veepelai respectively.

daun salam $n$. [Malay] An aromatic leaf used in Malay cooking which has a similar flavour to curry leaves.

2001 New Straits Times 23 Sept. What makes the nasi lemak so unusual is the addition of fenugreek (halba) that lends a certain aroma to the rice. Not to mention the slight hint of daun salam. 
Dewan Negara $n$. [Malay Dewan Hall, Assembly + Negara Nation] The national Senate.

2001 New Straits Times 8 Aug. Six syndicates were busted and 22 people arrested from January to March this year in connection with forged Malaysian identity cards, the Dewan Negara was told yesterday.

Dewan Rakyat $n$. [Malay Dewan Hall, Assembly + Rakyat "the people"] The national House of Representatives.

2001 New Straits Times 27 Oct. Abdullah reportedly advised MPs to raise any dissatisfaction with the Prime Minister first, instead of turning the Dewan Rakyat into a bashing ground.

dikir barat $n$. [Malay] A style of call-and-response singing originating in Kelantan.

2001 New Straits Times 3 Oct. You'll get to see groups bantering in dikir barat, hitting traditional drums, playing and dancing to traditional music.

dukun $n$. [Malay, orig. Javanese Malay] A medicine man, healer.

2001 The Star 20 Oct. The virtues of jamu were later introduced to the "common people" by native healers known as dukun (witch-doctor).

Friday prayers $n$. [Malay sembahyang Jumaat, orig. Arabic Jum'ah] Congregational prayer performed by Muslims every Friday afternoon.

2001 New Straits Times 25 Oct. A witness told the High Court today that he did not perform the Friday prayers on Dec 18, 1998, ....

gamelan $n$. [Malay, orig. Javanese Malay] A type of Javanese orchestra that has become an important part of the music culture of Malaysia.

2001 New Straits Times 27 Oct. The gamelan is a sound from our past, unique to this region and its people, its melodies a record of our forefathers' lives.

gasing $n$. [Malay] A giant top that weighs approximately $5 \mathrm{~kg}$. Top spinning competitions are held annually, especially in the east coast of Peninsular Malaysia, with the participants being adults rather than children.

2001 New Straits Times 19 Sept. A typical gasing is about the size of a dinner plate and may weigh about $5.5 \mathrm{~kg}$. Spinning gasing is hardly child's play as it requires strength, great dexterity and precise timing.

Comb.: gasing pangkah a top-spinning competition whereby a participant hurls his top at his opponent's in order to break or destabilise the latter; gasing uri a top-spinning competition whereby the participant tries to keep his top spinning for as long as possible.

2001 New Straits Times 18 Aug. Among the other events to be held are a chess tournament from Aug 30 to Sept 2 at the Putra World Trade Centre, a gasing pangkah competition from Sept 7 to 9 in Labuan, ....

gatal $a$. [Malay] Mischievous and flirtatious, usually of lecherous men.

2001 New Straits Times 13 Oct. Add in a gatal (lecherous) rich man (essential in ALL local movies) and a love triangle between Harry, Yati and Chantal, and there you have it: 90 minutes of entertainment.

God willing [Malay insyaallah, orig. Arabic] If God wills it. Many Muslims consider any expression of certainty about the future to be arrogant, and very often use this term to prefix any statement of positive intent or prediction, or agreement to do something. It is this suggestion of humility and knowledge that everything is in the hands of God that distinguishes the use of this term in ME. See also Insyaallah.

2001 The Star 10 Oct. "His Majesty also said that with the prayers of everyone, God willing, he will be returning home soon." 
gotong-royong $n$. [Malay] The traditional Malay practice of helping one another in communal projects, preparation for festivals, etc.

2001 New Straits Times 28 Nov. ... revive traditional practices like gotong-royong, visiting neighbours during festivals and helping neighbours who face problems.

Hajah $n$. Also Hajjah. [Malay] The title used by a woman who has performed the Haj pilgrimage to Mecca.

2001 The Star 16 Sept. The others are Mej-Jen Datuk Pahlawan Mohd Azumi Mohamed, Hajjah Salbiah Mohd Painah, Shell Companies in North-East Asia chairman Tan Eik Kia, former assemblyman and educationist Temenggong Tan Meng Chong, businessman and philanthropist Lee Chi Min and Reverend Made Katib.

Haji $n$. [Malay] The title used by a man who has performed the Haj pilgrimage to Mecca.

2001 The Star 23 Nov. "I had known the King since I was a little girl because my grandfather, Haji Kassim, was the imam of Istana Alam Shah (in Klang). He was very fond of children even then," she said.

halal $a$. [Malay, orig. Arabic] Permitted under Islamic law, usually in reference to food.

2001 New Straits Times 4 Nov. Of the switch to halal Chinese cuisine, he says that he and his kitchen team have been preparing for it for months, testing various ways to get similar or almost similar flavours and textures.

non-halal not permitted under Islamic law, usually in reference to food and restaurants.

2001 The Star 15 Aug. Shops that do not have a Chinese restaurant permit, even though they are Chinese-owned and have been selling other non-halal food like pork, cannot legally sell beer without the permit.

hantu $n$. [Malay] A spirit, ghost or demon.

2001 New Straits Times 26 Aug. I think most Malaysians believe in one kind of hantu or another.

haram $a$. [Malay, orig. Arabic] Forbidden by Islamic law.

2001 New Straits Times 2 Aug. Hassan said all 12 State Muftis at the meeting unanimously agreed that the council should decree black metal music as haram.

Hari Raya $n$. Also Hari Raya Puasa, Hari Raya Aidilfitri. [Malay hari day + raya celebration] The celebration marking the end of the fasting month.

2001 The Star 15 Dec. The Sultan of Selangor, Sultan Sharafuddin Idris Shah, will hold an open house at Istana Bukit Kayangan here on the first day of Hari Raya from noon to 3pm.

ikan bilis $n$. [Malay] 1 Dried anchovies. 2 Insignificant people, small fry.

12001 New Straits Times 17 Sept. Another Penang favourite is loh bak, which is an assortment of deep-fried fish balls, fish cake, crab sticks, tau hoo, cucur udang and other items cut into bitesize pieces and eaten with a special sauce, which is made from ikan bilis stock, seasoning and eggs. 22001 The Star 7 Nov. "We don't act only against the ikan bilis. Our action is against all, whether they are ikan bilis or king of illegal loggers," Rahim said during a highly spirited question hour that focused on issues of illegal logging, illegal immigrants and illegal fish bombings.

Comb.: sambal ikan bilis condiment made by cooking ikan bilis in chilli paste.

2001 The Star 20 Sept. "If the choice is nasi lemak, taken with a small serving of sambal ikan bilis, a slice of boiled egg, some slices of cucumber or fried kangkung, and a cup of coffee, hot chocolate or tea, that should be fine...."

ikan kembung $n$. [Malay] A local species of mackerel (Rastrelliger kanagurta).

2001 The Star 17 Nov. Sabariah Ismail, 43, said ikan kembung, normally costing RM5 a kilo, was sold between RM6 and RM8 per kilo. 
ikan tenggiri $n$. [Malay] Spanish mackerel (Scomberomorus commerson).

2001 The Star 5 Dec. "The standard price for other items which are not under the controlled list like ikan selar and ikan tenggiri were also not exorbitant."

ikan terubok $n$. [Malay] A sequential hermaphrodite fish from the herring family (Clupeidae) found mainly in Sarawak. Ikan terubok is sought after not only for its flesh but also for its roe.

2001 New Straits Times 16 Nov. To ensure that the ikan terubok continue to exist on a sustainable basis, we need to put in place some form of licensing for terubok catchers.

$\operatorname{imam} n$. [Malay, orig. Arabic] The man who leads prayers in a mosque.

2001 New Straits Times 5 Oct. They allegedly performed the prayers in a congregation separate from the one led by the imam appointed by the Federal Territory Islamic Religious Council, in contravention of a directive dated Aug 14 issued by the council.

Insyaallah Also InsyaAllah, Insya-Allah, insyallah. [Malay, orig. Arabic] If God wills it. Many Muslims consider any expression of certainty about the future to be arrogant, and very often use this term to prefix any statement of positive intent or prediction, or agreement to do something. See also God willing.

2001 New Straits Times 1 Oct. We are waiting for the time to sign the Articles of Agreement with the founding members that include Sudan, Indonesia, Bahrain, Brunei and the Islamic Development Bank, to effectively launch the IIFM project, Insyaallah this year.

Ipoh [Malay] Capital city of the Malaysian state of Perak.

2001 The Star 9 Dec. Like a treasure hunt, it takes a while to uncover Ipoh's culinary secrets, tucked as the food establishments are in little squatter settlements, wet markets and corner shops.

Islamic Affairs Council n. Also Islamic Council, Islamic Religious Council. [Malay Majlis Council + Agama Religion + Islam Islam] A state-level council responsible for formulating policies aimed at the advancement of Islam.

2001 The Star 3 Aug. All the state Islamic affairs council presidents were present at the meeting.

Islamic Affairs Department $n$. [Malay Jabatan Department + Hal Ehwal Affairs + Agama Religion + Islam Islam] A state-level department in charge of implementing policies and programmes formulated by the Islamic Affairs Council. Each state has either an Islamic Religious Department or an Islamic Affairs Department.

2001 The Star 30 Sept. Mentri Besar Datuk Seri Dr Mohd Khir Toyo said the students, all studying in universities in the Middle East, had been informed of the decision by the state Islamic Affairs Department.

Islamic Religious Department $n$. [Malay Jabatan Department + Agama Religion + Islam Islam] A state-level department in charge of implementing policies and programmes formulated by the Islamic Affairs Council. Each state has either an Islamic Religious Department or an Islamic Affairs Department.

2001 The Star 1 Aug. Dr Hilmi, who is the State Islamic Religious Council chairman said yesterday the Islamic Religious Department will be writing the sermons.

Isyak prayer (tautology) $n$. Pl. Isyak prayers. [Malay sembahyang Isyak, orig. Arabic Isha] The evening prayer - the last of the five daily prayers performed by Muslims.

2001 The Star 21 Nov. Strengthening neighbourhood ties can also be seen during the performance of the optional terawih and witir prayers at night after the compulsory Isyak prayer.

jaguh kampung $n$. Pl. jaguh kampungs. [Malay] An uncomplimentary term for an athlete who is only able to win when he or she plays on the home turf. 
2002 The Star 4 Jan. He has been in the national team for a long time and he has to break out of the shell in international tournaments ... we don't want to breed jaguh kampungs," said Zolkples.

jampi $n$. [Malay, orig. Sanskrit] Spell or charm.

2001 New Straits Times 4 Nov. Information Minister Tan Sri Khalil Yaakob, who took to the rostrum, must have sensed the politically charged atmosphere when he said: "If I can work some jampi (charm), I will try to bring about unity in MCA."

Comb.: air jampi water which has been subjected to an incantation.

Jawi $n$. [Malay] An adapted Arabic alphabet for writing the Malay language. It is used as one of two official scripts in Brunei, and is employed to a limited extent in Malaysia, Indonesia and Singapore as well, particularly in religious contexts.

2001 The Star 22 Oct. A UNIQUE attraction in the fishing village of Kuala Sepetang, about $17 \mathrm{~km}$ from Taiping, Perak, is a concrete signboard along Jalan Tepi Sungai with the name "Port Weld" rendered in four languages: English, Bahasa Malaysia (in Jawi script), Chinese and Tamil.

jembalang $n$. [Malay] An evil spirit.

2001 New Straits Times 10 Nov. After all, the air jampi will not lift a gypsy curse in Oxford. Neither will the Holy Water send the Malay jembalang (evil spirits) scurrying.

joget $n$. [Malay] Malay folk dance characterised by quick rhythmic movements.

2001 The Star 11 Nov. The Actors Studio Academy's traditional dance programme offers a choice of classical Malay dances such as Asyik and Trinai or folk dances like joget, zapin, endang and layang mas.

Johor $n$. Also Johore. [Malay] A state situated in the south of Peninsular Malaysia.

Johorean $n$. Pl. -s. A native or inhabitant of the state of Johor.

2001 The Star 5 Aug. The 23-year-old Johorean feels that he should be picked based on his victory in the men's $100 \mathrm{~m}$ event at the MAAU Open in Malacca last week.

kacang $n$. [Malay kacang peas, beans, lentils or nuts; orig. Tamil kaccaan] Roasted nuts, usually eaten as a snack.

2001 New Straits Times 23 Oct. I've rediscovered a passion for those films, now - I have quite a collection of James Bond movies! Not out of any fondness for the hero, but for the memories he evokes. Of me and my father, the Majestic and Sentosa cinemas in Petaling Jaya, Coke and kacang.

Comb.: ais/ice kacang local dessert of shaved ice, syrup, kidney beans, cream corn, sago, etc.; bubur kacang gruel made of various types of beans; putu kacang local biscuit made of mung bean meal and sugar.

2001 New Straits Times 23 Oct. For dessert, there is ais kacang with pastries and cakes.

kadi $n$. [Malay, orig. Arabic qadi] A judge in Islamic affairs.

2001 New Straits Times 31 Oct. Under the ruling, couples wanting to get married have to undergo the HIV test, the results of which must be handed to the kadi before the wedding.

kampung $n$. Pl. -s. [Malay] A small village.

Attrib.: kampung house [Malay rumah kampung] traditional (Malay) house on stilts, usually made of wood and with a thatched roof; kampung chicken [Malay ayam kampung] local breed of chicken usually raised in the backyard by rural folk using traditional methods and therefore regarded as having better meat quality.

2001 The Star 22 Sept. According to Sundram, British bikes were extensively used in the estates by management staff to get around. In addition, the police, army and postal services owned many too, especially BSAs of $250 \mathrm{cc}$ and $350 \mathrm{cc}$ capacities. Many are still around; quite a few rotting under kampung houses all over the country. 2001 New Straits Times 26 Aug. TCRS offers customers a choice of ordinary chicken or kampung chicken with a slight difference in prices.

Comb.: Malay kampung [Malay kampung Melayu] a Malay village. 
2001 New Straits Times 11 Sept. We are sitting in her library in a middle-class enclave surrounded by Malay kampungs in Selayang, Selangor, and she is talking animatedly about her latest project: implementing a community transport service in the Klang Valley for those unable to use, or who have difficulty in using, public transport.

kangkung $n$. [Malay] A semi-aquatic tropical plant (Ipomoea aquatica) grown as a leaf vegetable. Sometimes called water convolvulus.

kaya $n$. [Malay serikaya] Custard-like spread for bread made of coconut milk, sugar and eggs and flavoured with pandanus juice.

2001 The Star 20 Sept. Wholemeal bread toast with a thin spread of butter or kaya, could also be your breakfast.

kebaya $n$. Also baju kebaya. [Malay] A form-fitting blouse with frontal opening and long sleeves, traditionally worn by Peranakan and Malay women. Also a suit comprising such a blouse and a sarong or a form-fitting long skirt.

2001 New Straits Times 12 Aug. Dressed in black baju kebaya with a beige and blue floral motif, the mother of four was accompanied to accept her award by State Executive Councillor Datuk Kee Phaik Cheen and Penang Council of Datuks council member Datuk Saleena Yahaya-Isa.

Kedah $n$. [Malay] A state situated in the northwest region of Peninsular Malaysia.

Kedahan $n$. \& $a$. A $n$. Pl. -s. A native or inhabitant of the state of Kedah. B $a$. Of or relating to or characteristic of the state of Kedah or its people or language or culture.

A 2001 The Star 13 Dec. Next year will be Kedah-born Zahir's 20th as the Speaker. He is an inspiring figure to many Kedahans. B 2001 The Star 11 Nov. The venue is Rumah Penghulu Abu Seman bin Nayan located in Jalan Stonor (near the KLCC), a beautifully restored Kedahan Malay house that was "transplanted" to KL and now hosts Badan Warisan.

Kelantan $n$. [Malay] A state situated in the northeast region of Peninsular Malaysia.

Kelantanese $n$. Pl. same. A native or inhabitant of the state of Kelantan.

2001 New Straits Times 19 Sept. Kelantanese are renowned for their warmth and friendliness.

kemenyan $n$. [Malay] A type of incense made from the resin of a tree of the same name.

2001 New Straits Times 26 Aug. It is said that close to every Umno supreme council election, Dewan Merdeka at the Putra World Trade Centre in Kuala Lumpur would be filled with the smell of kemenyan (incense) and lilin (candle) as some candidates sought the help of their trusted bomoh and pawang to influence voting.

kenduri $n$. Pl. same, -s. [Malay, orig. Persian, Hindustani] A traditional Malay feast, often religious.

2001 New Straits Times 17 Sept. In addition, the expenses are high because the host has to feed the volunteers days before the kenduri ....

kerabu $n$. [Malay] Malay salad.

2001 New Straits Times 26 Nov. Break fast with dates and whet your appetite with kerabu, ulam and sambal ....

Comb.: nasi kerabu salad of rice, herbs and other greens.

kerisik $n$. [Malay] Lightly-roasted grated coconut. Not to be confused with desiccated coconut.

2001 New Straits Times 22 Aug. "City folk especially do not use stuff like kerisik, handsqueezed coconut milk, rempah-rempah (spices), real pandan leaf extracts for colouring and taste, ..."

keroncong $n$. Also kroncong. [Malay, orig. Javanese Malay] A type of Javanese music and song performance that has some Portuguese influence. 
2001 New Straits Times 27 Oct. My personal favourite for the evening was definitely Suasana, a piece that used a range of musical styles such as the Terengganu gamelan, keroncong, asli singing style, kompang/rebana drums, the rebab and vocals.

kerongsang $n$. Pl. -s. [Malay] A set of three decorative brooches worn on the lapel of a baju kebaya, traditionally used in place of buttons.

Comb.: ibu kerongsang the biggest of the three brooches that make up a kerongsang.

2001 New Straits Times 26 Nov. Traditional jewellery is actually an amalgamation of our diversified cultures, Tan reveals. For instance, a ruby-studded ibu kerongsang in his collection shows Sri Lankan influence.

ketupat $n$. [Malay] Rice cakes made by cooking rice in small casings made of palm leaves.

2001 The Star 11 Dec. The island's assistant resort manager ... also used the opportunity to learn to make ketupat.

khalwat $a$. [Malay, orig. Arabic] Related to the offence, under the Syariah law of Malaysia, of being in an isolated place and in close proximity with a person of the opposite sex who is not one's spouse.

2001 The Star 19 Aug. A gotong-royong turned into a khalwat raid when Chief Minister Datuk Wira Mohd Ali Rustam, suspecting human presence in an abandoned house in Kampung Morten, instructed those involved in the cleanliness campaign to check the place.

kompang $n$. [Malay] Shallow-frame hand-held Malay drum, usually played in processions.

kompang troupe [Malay kumpulan kompang] kompang ensemble.

2001 New Straits Times 18 Aug. We arrived at the resort at 6pm, and were welcomed by a kompang troupe, Azwan and several artistes who had arrived earlier.

Kota Kinabalu $n$. Capital town of the Malaysian state of Sabah.

2001 The Star 26 Sept. KOTA KINABALU: National bowler Ng Yiew Hup defeated United States's Purvis Granger over two games in the step-ladder grand finals of the inaugural Kota Kinabalu International Open Championships at the CPS Bowl here on Monday night.

Kuala Lumpur $n$. [Malay] Also KL. (Abbrev.) Capital city of Malaysia, Kuala Lumpur.

KL-ites $n$. Usu. in pl. Natives or inhabitants of KL.

2001 The Star 25 Aug. Originally from Kuala Lumpur, he's been here for the last seven years. 2002 The Star 18 Jan. And in their bid to become the first team to win back-to-back world titles, the Dutch realise that they need all the help in getting used to the conditions in KL. $2001 \mathrm{New}$ Straits Times 4 Nov. Rainy days and Monday, Oct 29, really got KL-ites down. Another day that will go into the records as one of Kuala Lumpur's "worst" flash floods. The way it's going, it promises to be worse when the next big one strikes.

Kuantan $n$. [Malay] The capital town of the Malaysian state of Pahang.

2002 The Star 4 Jan. Kapten Nazri cheated death on Wednesday when the Pilatus aircraft he was piloting crashed off the Kuantan coastline.

Kuching $n$. [Malay] Capital city of the Malaysian state of Sarawak.

2001 The Star 3 Aug. KUCHING: The fate of the five Sarawak Premier League players, suspended over allegations of drug abuse, will be known when the FA of Sarawak's (FAS) disciplinary board meet today.

kuih $n$. Pl. same, kuih-muih, kuih-kuih. [Malay, orig. Batavia Malay, Penang Malay] Any type of local cakes, puddings, biscuits, pastries and fritters, made variously from glutinous rice flour, rice flour, wheat flour, cane sugar, palm sugar, coconut milk, grated coconut and eggs.

2001 New Straits Times 6 Nov. For dessert, check out ais kacang, assorted ice cream, bread and butter pudding, iced longan and jelly, kuih, French pastries and fresh fruits 
Comb.: kuih bahulu small cupcake, traditionally baked over charcoal fire in cast iron moulds; kuih bangkit light biscuit made of coconut milk, sugar and rice flour; kuih kapit thin wafer made from wheat flour, coconut milk, sugar and eggs.

kunyit $n$. [Malay] Turmeric.

2001 New Straits Times 23 Sept. Chew it slowly and enjoy the release of aroma from the serai, daun kadok, daun limau purut, daun kunyit, shallots, kunyit, dried prawns, salted fish and kerisik.

langsat $n$. [Malay] The oval, greyish-yellow edible fruit of a tree native to Malaysia and Indonesia (Lansium domesticum).

2001 New Straits Times 28 Nov. ... visitors are offered such local fruits as durian, langsat, dokong, rambutan and cempedak, among others.

Comb.: duku langsat a sweeter variety of langsat, this fruit has a slightly thicker skin.

Lembaga Tabung Haji $n$. Also Tabung Haji, Tabung Haji Board [Malay Lembaga Tabung Haji]. Pilgrims Fund Board, a fund management board that helps Muslims in Malaysia to invest in ways accepted under Islamic principles so that they may have the financial means to go on a pilgrimage to Mecca.

2001 New Straits Times 16 Aug. The Government will restructure Lembaga Tabung Haji to address the organisation's weaknesses and enable it to perform better.

lontong $n$. [Malay] A dish of rice cakes in a gravy of coconut milk, vegetables and spices.

2001 The Star 20 Sept. “... Sometimes I take lontong or a bowl of vermicelli soup. ...”

$\operatorname{madrasah} n$. Pl. same, -s. [Malay, orig. Arabic] An Islamic school.

2001 New Straits Times 10 Nov. Speaking to reporters later, Dr Mahathir said misinterpretation of Islamic teaching was rampant, especially among Muslim countries. "The Government has to correct the wrong teaching of Islam because children in the madrasahs and pondoks are taught to hate and fight the Government."

makan $n$. [Malay] 1 A meal or feast. 2 Eating or feasting, usually with family or friends.

12001 New Straits Times 26 Aug. The coming weekend will be a long holiday for most people .... Naturally, Malaysians will celebrate the way they know best - with a good makan. 22001 The Star 10 Sept. This activity is for seniors especially the widowed, divorced, single or separated to get together for fellowship, to share, learn and also take part in group activities like learning computer skills, dancing, exercising, sightseeing and, of course, makan.

Comb.: makan kecil a party where snacks and drinks are served.

2001 New Straits Times 21 Oct. There was a makan kecil at school, handled by the Student Council members, then a trip out to the beach ("Malaysia's Waikiki"), and finally a call on Vic and Jane Buzdon, where there was much reminiscing about Hilo days.

makcik $n$. [Malay] 1 A title of respect for a middle-aged Malay woman. The tile (usually with an initial capital) often precedes the name. 2 Pl. -s. A middle-aged Malay woman.

12001 The Star 15 Dec. Makcik Siah, 60, is one of the very few people who still labour over the hot stove to churn out traditional delicacies for Hari Raya. 22001 New Straits Times 22 Aug. I have spent close to 10 years talking with the kampung 'makciks' and other sources to unlock the secrets of Malay food, especially preparing them traditionally like how our forefathers did.

Malacca $n$. Also Melaka. [Malay] 1 A state situated on the west coast of Peninsular Malaysia, noted for its historic sites. 2 The capital city of the state of Malacca.

Malaccan $n . \& a$. A $n$. A native of inhabitant of the state of Malacca. B $a$. Of or relating to or characteristic of the state of Malacca or its people or language or culture.

2001 The Star 30 Oct. A true-blue Malaccan Straits Chinese, Tan teaches us to distinguish between the cooking styles of Penang and Malacca Nyonya. 
Malaysia Boleh spirit $n$. [Malay semangat Malaysia Boleh] "Malaysia Boleh" (lit. "Malaysia can") is a slogan used to promote national pride. The can-do attitude encapsulated in this slogan became known as the Malaysia Boleh spirit.

2001 The Star 16 Oct. I've read of the biggest mooncake, the longest teh tarik, the biggest roti canai, the longest chain of diners, etc, all of which did nothing to strengthen the Malaysia Boleh spirit.

Malaysian Islamic Economic Development Foundation $n$. [Malay Yayasan Foundation + Pembangunan Development + Ekonomi Economy/Economic + Islam Islam/Islamic + Malaysia Malaysia, also YPEIM] Established in 1976 by the Federal Government, the foundation oversees the economic development of the Muslim community in Malaysia.

2001 New Straits Times 6 Aug. Seventeen years after its re-birth, Malaysian Islamic Economic Development Foundation (YPEIM) can be proud of its achievement in helping the hardore poor and supporting petty traders.

$\operatorname{mamak} n$. [Malay, orig. Tamil] An Indian Muslim.

2001 New Straits Times 4 Nov. It does not matter whether one is a Javanese, a Mamak, a peranakan Arab or an Orang Asli. The question is: what does it mean to be a Malay?

mamak stall [Malay gerai mamak, warung mamak] stall run by an Indian Muslim, usually selling humble fare like roti canai, local kuihs, noodles, teh tarik, etc.

2001 New Straits Times 29 Sept. "Sometimes, it can be really tiring as I hate putting on makeup. I'm a jeans and T-shirt girl who loves sitting at mamak stalls but I can't do that too often now," she says.

Mat Salleh $n$. \& a. Malay slang. [Malay] A $n$. A Caucasian person. B $a$. Of or pertaining to a Caucasian.

12001 The Star 14 Sept. The mat salleh might not look very intimidating now but some of them do appear rather imperious in the pages of this volume, especially when they were our colonial rulers. 22001 New Straits Times 1 Oct. I think because Brian is Mat Salleh and I'm local, the comedic elements come in when the two cultures meet.

mee goreng $n$. [Malay, orig. Hokkien mee noodles + Malay goreng fried] Fried wheat noodles, usually spicy.

2001 The Star 15 Dec. For those who enjoy roti canai, mee goreng, nasi goreng or kuey teow goreng, there are various stalls offering these along the Pasir Bogak stretch.

mee rebus $n$. [Malay, orig. Hokkien mee noodles + Malay rebus boiled] Wheat noodles in a spicy sauce.

mengkuang mat $n$. [Malay tikar mengkuang] A mat woven from the leaves of the mengkuang, a type of screw pine with long and broad leaves.

2001 New Straits Times 5 Sept. Malaysia's traditional crafts like the batik sarong, rattan products and mengkuang mats are being elevated to new heights thanks to the creative women in the industry as shown in the "Women in Craft" event held at the Kuala Lumpur Craft Complex recently to celebrate and appreciate their work.

Menteri Besar $n$. Pl. Menteris Besar. [Malay Menteri Minister + Besar Big] Chief Minister for any of the nine former Federated and non-Federated Malay states.

2001 The Star 19 Aug. The Menteri Besar has been so pleased with Yee's book that the state government purchased over 600 copies to be distributed to students in Sabak Bernam.

Merdeka spirit $n$. [Malay semangat Merdeka] Spirit of independence.

2001 New Straits Times 30 Aug. Menteri Besar Datuk Seri Tajol Rosli Ghazali has urged the people to show their Merdeka spirit by flying the national flag at their premises. 
Muar $n$. [Malay] An old town in Johor on the west coast of Peninsular Malaysia.

2001 The Star 7 Nov. "I am truly overwhelmed by their generosity," says the Muar-born beauty who is pursuing a degree in Science and Psychology at the University of North British Columbia in Canada.

muhibbah $a$. [Malay muhibah] Harmonious, associated with good will and friendship among different groups of the society.

2001 New Straits Times 19 Oct. The five kids in the band incidentally are a muhibbah bunch Harry (the delicious Craig Fong) is the Chinese deejay who formed the band; Yati (Ellie Suriaty Omar) is a Malay girl who plays the bass; Chantal (Corinne Adri) is the Eurasian vocalist; Ariff (Edwin R Sumun) adds flavour to the group as the flamboyantly gay keyboardist, and JJ (Sanjeet Jarnail) is the Indian drummer.

naan bread (tautology) $n$. [Malay roti naan, orig. Hindustani naan] Naan, a type of unleavened bread baked in a tandoor.

2001 New Straits Times 5 Sept. Ask for the minced beef tandoori and naan bread ....

nasi lemak $n$. [Malay nasi rice + lemak rich, oily] Rice cooked in coconut milk, usually served with sambal, and traditionally wrapped in a banana leaf.

nasi lemak stall $n$. [Malay gerai nasi lemak, warung nasi lemak] stall selling nasi lemak, snacks and drinks.

2001 New Straits Times 15 Oct. In the not-too-distant past, the phrase woman entrepreneur would more likely than not conjure the picture of a makcik minding her nasi lemak stall in the morning, a preoccupation that takes part of her day, before she goes home to mind the husband and her family.

Negri Sembilan $n$. Also Negeri Sembilan. [Malay] A state situated on the west coast of Peninsular Malaysia.

2001 The Star 19 Aug. Kolej Tunku Kurshiah in Negeri Sembilan bagged two major awards for best SPM academic performance and for best overall academic achievement last year.

night market $n$. P1. night markets. [Malay pasar market + malam night] A market place where itinerant traders gather at night to sell fresh produce, food, clothing, flowers, trinkets, CDs, DVDs, etc.

2001 The Star 25 Dec. Church members sold pastries and cakes in a night market to collect the money for the refugees, he said after handing the money to The Star's Afghan Refugees Fund during a Christmas high tea at the centre on Sunday.

nyonya $n$. \& $a$. [Malay] A $n$. Pl. -s. The women folk of the Straits Chinese community. B $a$. Of cuisine, food, culture, fashion, cooking, restaurant, etc.: pertaining to the Straits Chinese.

2001 The Star 30 Oct. The Malaccan Nyonyas add fragrant leaves, flowers and herbs to enhance their cooking. 2001 The Star 30 Oct. Nyonya cuisine is synonymous with sumptuous food by fastidious and meticulous cooks who take pride in their cooking.

orang asli $n$. \& $a$. [Malay orang people + asli original] A $n$. Pl. same. The aboriginal peoples of the Malay Peninsula, Sabah and Sarawak, comprising various nomadic and sedentary groups and tribes. B $a$. Of or pertaining to the aboriginal peoples of Malaysia.

A 2001 New Straits Times 3 Sept. To date, 24 Orang Asli had been trained as excavator operators and 40 others were working in various positions at the worksite, he said. B 2001 The Star 23 Aug. Since both nomadic and sedentarised orang asli groups are facing a demographic crisis, the theory that resettlement has helped to develop them economically and socially is possibly untrue except under conditions where economic development is designed to benefit them directly. 
Orang Asli Affairs Department $n$. Also Department of Orang Asli Affairs. [Malay Jabatan Hal Ehwal Orang Asli] A government department that oversees the economic development of the Orang Asli community.

2001 The Star 30 Oct. The project, a joint venture between Risda and the Pahang Orang Asli Affairs Department, is intended to benefit about 100 orang asli families living nearby.

orang minyak $n$. [Malay orang people + minyak oil] A demon whose skin is believed to be shiny, black and oily. Of Malay folklore.

2001 New Straits Times 13 Oct. Last month, on Sept 22, a bomoh, witnessed by villagers in Kuala Kedah, purportedly trapped an orang minyak, an oily, or rather, a slippery bogey man who, in Malay myth, is believed to prey on virgins.

orang putih $n$. [Malay orang people + putih white] A Caucasian.

12001 The Star 23 Aug. He said the commission seemed disinclined to make an independent decision based on Malaysian values, fearing that it would not be praised by the orang putih (whites).

Orang Ulu $n$. \& $a$. [Malay orang people $+u l u$ upriver] A $n$. A catch-all phrase used to describe a large number of upriver tribes in Sarawak, including the Kayan, Kenyah, Kajang, Kejaman, Punan, Ukit and Penan tribes. B $a$. Of or pertaining to any of the upriver tribes of Sarawak.

2001 The Star 26 Sept. Several Orang Ulu leaders such as Senator Joseph Balan Seling, a former Telang Usan assemblyman, have been campaigning there to convince the Orang Ulu to close ranks and vote for the party.

outrage ... modesty $v$. [Malay mencabul to violate + kehormatan self-respect] To molest; to abuse sexually.

2001 New Straits Times 28 Aug. He was commenting on a newspaper report today which said a doctor had allegedly outraged the modesty of a 25 -year-old woman on the pretext of carrying out a "thorough body check".

outraging the modesty (of) $n$. the action of molesting someone.

2001 New Straits Times 23 Oct. In August 2001, Iwabuchi was sentenced by the Sessions Court to eight years' jail and ordered to be given 10 strokes of the rotan for outraging the modesty of a woman.

Pahang $n$. [Malay] A state situated on the east coast of Peninsular Malaysia.

Pahangite $n$. Pl. -s. A native or inhabitant of the state of Pahang.

2001 New Straits Times 24 Aug. The VSPD said in the Bentong district - the place where Genting Highlands is located - such units currently command a median price of RM175,000, while in Cameron Highlands, it is RM142,750 and in Kuantan, RM165,000. Needless to say, such units are not intended to appeal to the majority of Pahangites. Instead, they are aimed at purchasers from other states as well as foreigners who can afford a getaway home in one of the state's natural attractions.

pakcik $n$. [Malay] 1 A title of respect for a middle-aged Malay man. The tile (usually with an initial capital) often precedes the name. 2 Pl. -s. A middle-aged Malay man.

12001 The Star 2 Sept. At the shop set up by the middleman, Pakcik Zin is busy sorting out the bananas that have been brought in by the farmers.

pandan $n$. [Malay] Pandanus, a type of screw pine. The pandan leaves can be woven into baskets and mats while the juice extracted from the leaves is used to flavour savoury as well as sweet dishes.

2001 New Straits Times 29 Oct. ... she felt that pandan was underexploited as a raw material for handicraft.

Attrib. \& Comb.: pandan leaf [Malay daun pandan] the leaf of the pandanus from which pandan juice is extracted; pandan mat [Malay tikar pandan] mat woven from pandan leaves; pandan jelly [Malay agar-agar pandan] pandan-flavoured jelly. 
2001 New Straits Times 29 Oct. Bajau women in Sabah, for instance, weave exquisite pandan mats, incorporating intricate designs which reflected their historical and cultural bonds with the Philippines.

pantun $n$. [Malay] A type of didactic verse that can be recited or sung.

2001 The Star 19 Aug. Despite a cold morning drizzle, the children eagerly assembled in the assembly ground, where they sang .... They also presented a pantun and dance ....

parang $n$. Pl. -s, same. [Malay] A short, heavy, straight-edged knife used in Malaysia and Indonesia as a tool and weapon.

2001 New Straits Times 10 Nov. Two men armed with parangs robbed a MBf Finance branch in Taman Maluri, Cheras of RM72,000 today.

pasar malam $n$. Pl. same. [Malay] A night market.

2001 The Star 13 Aug. In Shah Alam, the Selangor Government's ban on VCD and videotape sales at pasar malam and five-foot ways has forced traders to operate their businesses from the boots of their cars, reports Elan Perumal.

pasar tani $n$. Pl. same. [Malay] A farmers' market.

2001 New Straits Times 12 Nov. "Farmers who have been marketing their produce at farmers' markets or pasar tani managed by Fama will have a more comfortable place to carry out their business when terminals are completed," he said ....

pawang $n$. [Malay] A traditional Malay medicine man believed to be capable of exorcising illnesses, driving out bad luck, etc.

2001 New Straits Times 26 Aug. It is said that close to every Umno supreme council election, Dewan Merdeka at the Putra World Trade Centre in Kuala Lumpur would be filled with the smell of kemenyan (incense) and lilin (candle) as some candidates sought the help of their trusted bomoh and pawang to influence voting.

pelamin $n$. [Malay] A Malay bridal dais where the bride and the groom sit during the bersanding ceremony.

2001 New Straits Times 2 Nov. The pelamin is an integral part of the Malay wedding ceremony. It is a decorated platform on which newlyweds sit for the bersanding ceremony.

Penang $n$. Also Pulau Pinang. [Malay] A state on the west coast of Peninsular Malaysia, comprising an island and a thin strip of land on the Peninsula.

Penangite $n$. Pl. -s. A native or inhabitant of the state of Penang.

2001 The Star 22 Oct. The decision by Malaysia Airlines to discontinue its Penang-PhuketPenang service effective end of this month came as a shock to many as it is a popular destination among Penangites and other northerners.

Perak $n$. [Malay] A state situated on the west coast of Peninsular Malaysia.

2001 The Star 10 Oct. The 19 Al-Ma'unah members have been ordered to enter their defence on a charge of waging war against the Yang di-Pertuan Agong at three places in Perak, from June to July 6. The charge, under Section 121 of the Penal Code, carries the death sentence or life imprisonment if convicted.

Peranakan a. [Malay] Of cuisine, culture, etc.: pertaining to the Peranakan community - the descendants of the $17^{\text {th }}$ - and $18^{\text {th }}$-Century Chinese seafarers and their local wives. Also Baba, Nyonya.

2001 The Star 29 Dec. ... Seri Nyonya also serves up hard-to-find Peranakan dishes such as Hee Peow Soup and Ikan Goreng Cili Garam.

Comb.: peranakan Arab (rare) descendants of early Arab traders and their local wives.

2001 New Straits Times 4 Nov. It does not matter whether one is a Javanese, a Mamak, a peranakan Arab or an Orang Asli. The question is: what does it mean to be a Malay? 
Perlis $n$. [Malay] The smallest state in Malaysia, situated in the northwest region of the Peninsula.

2001 The Star 25 Dec. MCA leaders yesterday pledged to set aside their differences to work together and ensure victory for the Barisan Nasional in the Indera Kayangan by-election in Perlis.

petai $n$. [Malay] The strong-smelling green seeds of a long, flat bean (Parkia speciosa), used in Malay cooking. The seeds can be cooked or eaten raw dipped in a spicy sambal.

2001 New Straits Times 18 Nov. ... the sambal has the right touch of pedas to bring out the best of the prawns and petai.

Comb.: sambal petai petai cooked in a chilli paste; sambal udang petai a spicy dish of petai and prawns in a chilli paste.

2001 New Straits Times 25 Sept. Another thing about Gerald is that he consumes sambal petai like ice-cream. 2001 New Straits Times 18 Nov. Another item to look out for is the sambal udang petai.

pondok $n$. Pl. -s. [Malay] 1 An Islamic school, usually in small villages. Also sekolah pondok, pondok school [Malay sekolah pondok]. 2 Small hut.

12002 The Star 28 Jan. "The sekolah pondok is not a fossil. If you want your children to have an Islamic education, the pondok still offers the best option ...," said Zaidi. 22001 New Straits Times 30 Aug. Earlier, Ibrahim told the court that at 10am on April 1, last year, Azhar, Mohd Rais and Abdul Aziz had asked him to meet them at a pondok (hut) near his (Ibrahim's) house where Azhar was also staying.

Comb.: pondok polis a hut that houses a small police station, usually found in small villages.

2001 The Star 25 Aug. There used to be a pondok polis nearby. When it was here, the crime rate was low.

pongteh chicken $n$. Also chicken pongteh, ayam pongteh. [Baba Malay ayam pongteh] A chicken stew with preserved soy bean paste, a traditional Peranakan dish.

2001 New Straits Times 23 Sept. I had never really thought much of pongteh chicken but I must admit Queenie has given it a new perspective.

pontianak $n$. [Malay] A female vampire.

2001 The Star 2 Sept. Many would be able to remember how their grandmothers would scare them with ghost stories about the beautiful pontianak (female vampire) who lived in the heart of banana trees and led young men astray, with often fatal consequences.

Puan Sri $n$. [Malay] The title reserved for the wife of a person who has been awarded the title of Tan Sri.

2001 The Star 15 Nov. In Seremban, Negri Sembilan Mentri Besar Tan Sri Mohamed Isa Abdul Samad and his wife Puan Sri Hazizah Tumin went to the open house of several Hindu leaders, including that of former state executive councillor Datuk Muthu Palaniappan in Jalan Labu Lama.

putu beras $n$. [Malay] A type of Malay biscuit made of rice meal and sugar.

putu kacang $n$. [Malay] A local biscuit made of mung bean meal and sugar.

Raja $n$. [Malay, orig. Indian] The sovereign of the state of Perlis.

2001 The Star 31 Dec. On Dec 13, the Raja of Perlis, Tuanku Syed Sirajuddin Syed Putra Jamalullail, is elected the 12th Yang di-Pertuan Agong by the Conference of Rulers during a special meeting at Istana Negara.

Raja Permaisuri Agong $n$. [Malay] 1 The official title of the consort of the Yang di-Pertuan Agung, the head of state of Malaysia. 2 The consort of the Yang di-Pertuan Agung.

12001 The Star 23 Nov. The Raja Permaisuri Agong Tuanku Siti Aishah, Malay Rulers and members of the royalty were present at the ceremony. 22001 New Straits Times 22 Nov. "The 
House records its profound sadness on the demise. On behalf of the House, we offer our condolences to the Raja Permaisuri Agong and the royal family."

rakyat $n$. [Malay] The common people (as opposed to the government or the aristocracy) of Malaysia.

2001 New Straits Times 28 Aug. For Ayub, this statement reflects the capricious ideologies spread by certain quarters who take advantage of the leeway afforded them by turning the rakyat against the Government.

Ramadan $n$. Also Ramadhan. [Malay, orig. Arabic] The ninth month of the Islamic calendar, when Muslims fast during the day and break the fast in the evening.

2001 The Star 21 Nov. Ramadan is not just about fasting during the daytime. It goes beyond that. The holy month of Ramadan is also a training ground for Muslims to cultivate good character.

rebab [Malay, orig. Arabic] A two-stringed fiddle believed to have originated in Arabia or Persia, and closely associated with Islamic culture.

2001 New Straits Times 7 Sept. At the same time, traditional performers inserted another dimension into Antara Semangat by using ethnic instruments like the rebab, serunai and gendang.

rebana $n$. [Malay] A Malay single-headed drum.

Comb.: rebana ubi very large rebana that can be hung vertically or placed horizontally on the floor.

2001 New Straits Times 19 Sept. Thirty years ago men used their hands to beat the rebana ubi but players in their impetuous enthusiasm are oblivious to the fact that the palms of their hands were cut or bruised. This interfered with their work, thus padded drumsticks are now used interchangeably.

rempah $n$. [Malay] Spices.

Comb.: wet rempah [Malay rempah basah] A combination of spices ground or blended with a little water to form a paste.

2001 New Straits Times 18 Nov. So we marinate the deer the day before, using local herbs like daun ketumbar, kurma powder, ginger, serai and wet rempah...

rendang $n$. [Malay] A spicy meat dish with a rich and fragrant gravy.

2001 The Star 23 Dec. More than 100 food stalls offering local favourites such as laksa Johor, ketupat, rendang, soto, rojak, lontong and traditional cakes ensured a free flow of food for guests.

Comb.: beef rendang [Malay rendang daging] spicy beef dish with a rich coconut gravy; chicken rendang [Malay rendang ayam] spicy chicken dish with a rich coconut gravy.

2001 The Star 2 Sept. We naturally like to learn new things, and turning out a fragrant apple pie or dishing out a plate of mouth-watering beef rendang from your own kitchen can be very satisfying. 2001 The Star 27 Dec. In Malacca, Christmas joy was visible in the Portuguese settlements of Ujong Pasir and Bandar Hilir where guests were served with the special dish of "karisenko" (chicken rendang with long beans).

rice bowl n. [Malay periuk pot + nasi rice] 1 Pl. rice bowls. Means of livelihood. 2 A reference to Kedah, the most important rice-producing state in Malaysia.

12002 The Star 24 Jan. These people are truly selfish and think nothing of throwing sand in the rakyat's rice bowl. 22001 The Star 15 Nov. ... Kedah is the "rice bowl" of Malaysia.

rojak $n$. [Malay] 1 A vegetable and fruit salad with a spicy dressing. 2 A confused collection or mixture - hodgepodge.

12001 New Straits Times 15 Oct. Spokesman for the buyers, Satiayawani Arumugan, said most of them were from the lower-income group and performed odd jobs like selling cendol and rojak. 2 2001 The Star 22 Sept. "The bike was in a bad state when I got it for RM2,500 eight years ago," says Azahar who spent a further RM3,000 to get it all spruced-up and smartened. He sourced parts from all over - "Rojak," Azahar says - scavenging used ones as well as ordering new parts. 
ronggeng $n$. [Malay] Malay social dance in which couples dance and exchange verses to the accompaniment of a violin and drums.

2001 The Star 1 Nov. Believed to have developed during the post-Portuguese period in Malacca, ronggeng became a popular form of entertainment at Baba and Malay weddings and other festivities in Penang in pre-war days.

rotan $n$. [Malay] $n .1$ A rattan cane used for inflicting judicially-sanctioned corporal punishment in Malaysia. 2 Any of various climbing plants of tropical Asia, having long, tough, slender stems. 3 (rare) A cane. 4 (rare) Judicially-sanctioned caning in Malaysia.

12001 New Straits Times 5 Sept. In allowing Tan's appeal, the court sentenced him to 15 years' jail and 10 strokes of the rotan for dadah possession. 32002 The Star 24 Jan. ... are jointly charged with voluntarily causing grievous hurt to nine-year-old Teoh Lee Sean by using a rotan between Oct 2000 and July 10 last year at Jalan Tiram in Cheras. 42001 New Straits Times 18 Aug. He also said he understood that he could be sentenced to a maximum 20 years jail and rotan for the offence.

roti $n$. [Malay, orig. Hindustani] Bread, usually the local version of a white loaf, which is slightly sweet and has a very soft texture.

Comb.: roti canai South-Indian fried bread usually eaten with curry; roti jala lacy pancake usually eaten with curry; roti kaya toast spread with kaya, often served as breakfast and morning tea fare in Chinese coffeeshops in Malaysia.

2001 The Star 20 Sept. Chef Wan seldom takes roti canai or nasi lemak because they are "nutritionally unbalanced."

Sabah $n$. [Malay] A Malaysian state situated on the northeast coast of the island of Borneo.

Sabahan $n$. \& $a$. A $n$. Pl. -s. A native or inhabitant of the state of Sabah. B $a$. Of or relating to or characteristic of the state of Sabah or its people or language or culture.

A 2001 The Star 21 Nov. In another development, another Sabah player, striker Rizal Awang $\mathrm{Jad}$, is set to play for Sarawak. If he seals the deal, he will be the second Sabahan in the Sarawak team. B 2001 The Star 21 Nov. The competition rules required them to buy the fabrics for their designs for one formal/evening outfit, a haute couture piece and a casual creation, all under one theme. The required fabrics ranged from songket, kain tenun, tjanting batik, pua kumbu to dastar (an ethnic Sabahan fabric traditionally used for headgear) for the first two categories and cotton batik, pua and dastar for the casual wear.

sajak $n$. [Malay] Various types of modern Malay poems.

2001 New Straits Times Apart from being a member in her school's debating team, she represented it in elocution and sajak recitation contests and organised a fund-raising drive during Hari Pahlawan.

sambal $n$. [Malay, orig. Tamil sambaar] Spicy condiment made variously from chillies, tamarind, shrimp paste, etc.

2001 New Straits Times 28 Nov. "Over 70 per cent of our stay-in guests are local business travellers, thus even our food and beverage outlets cater for them. The coffee house serves mainly Malay food because locals tend to miss their sambal and "warong' dishes."

Comb.: sambal belacan condiment of pounded chillies and dried shrimp paste; sambal ikan bilis condiment of chilli paste and dried anchovies; sambal petai condiment of chilli paste and petai.

Sarawak $n$. [Malay] The biggest state in Malaysia, situated on the north coast of Borneo.

Sarawakian $n$. \& $a$. A $n$. Pl. -s. A native or inhabitant of the state of Sarawak. B $a$. Of or relating to or characteristic of the state of Sarawak or its people or language or culture.

A 2001 The Star 6 Sept. Ironman Wong Tee Kui's hopes of retaining the gold medal in the SEA Games men's hammer event took a severe jolt yesterday when the 37-year-old Sarawakian aggravated a hamstring injury while training in Bukit Jalil. B 2001 New Straits Times 8 Aug. 
Sharifah Kirana showcased a fusion of East and West eveningwear. Sarawakian designer Tom Abang Saufi put on a collection with Sarawakian motifs. Bill Keith's collection of dazzling designs added glitter to the occasion.

saree cloth (tautology) $n$. [Malay kain sari, orig. Sanskrit, Hindi, Urdu sari] A long piece of fabric that is worn over a petticoat by Indian women.

2001 New Straits Times 16 Aug. Materials used include songket, linen, Chinese brocade, saree cloth and casa rubie (Indonesia's finest cotton).

sarong $n$. Also sarung. Pl. -s. [Malay] A tubular garment that is worn by wrapping it around the waist and tying it in such a way that it stays in place without a belt.

2001 New Straits Times 12 Nov. This type of batik dates back to 1793 and was commonly worn as a sarong or as a shawl by women in the palace in Terengganu.

Comb.: batik sarong batik worn as a sarong

2001 New Straits Times 16 Aug. ... cheongsam tops that can be teamed with batik sarong, pareos, pants and even jeans and comfy three-quarter pants.

Selangor $n$. [Malay] A state situated on the west coast of Peninsular Malaysia.

Selangorian $n$. A native or inhabitant of the state of Selangor.

2001 New Straits Times 26 Aug. Being a transplanted Selangorian, who lived in Hulu Langat, Bandar Baru Bangi and Subang Jaya for more than 30 years, I think I can make a fairly accurate judgment of the State's deteriorating natural environment.

selendang $n$. [Malay] A shawl that is generally worn with baju kurung or baju kebaya.

2001 New Straits Times 23 Oct. The dancers from Perak were all clad in purple Putri costumes and selendang.

sepak takraw $n$. [Malay, orig. Malay sepak to kick + Thai takraw woven ball] A Southeast Asian game whereby two teams of three players each use their feet and heads to send a hard rattan or plastic ball back and forth over a net.

2001 New Straits Times 12 Nov. The games that were contested during the first phase of the sports carnival in Penang were soccer, netball, sepak takraw, swimming, hockey, tenpin bowling, tennis, badminton and table tennis.

serai $n$. [Malay] Lemongrass.

2001 New Straits Times 18 Nov. So we marinate the deer the day before, using local herbs like daun ketumbar, kurma powder, ginger, serai...

silat $n$. [Malay] A type of Malay martial art.

2001 New Straits Times 20 Aug. Silat has its roots as far back as 6 AD when it was formalised as a combative system.

Comb.: silat olahraga competitive silat, silat as a sport.

2001 New Straits Times 20 Aug. However, there are those who feel that silat olahraga will compromise its combative value.

songket $n$. Also kain songket. [Malay] A traditional Malay hand-woven fabric with gold and silver threads, usually worn during official functions and ceremonies.

2001 New Straits Times 5 Sept. Some of the great crafts produced were the award-winning kain songket which has broken away from the usual repetitive motif and instead has a flowing floral motif that runs boldly across the material by Habibah Zikri from Kuala Terengganu.

songkok $n$. [Malay] A velvet foldable oblong hat worn by Malay men.

2001 New Straits Times 30 Aug. "Some of the Chinese even resorted to wearing the songkok to deceive the Japanese soldiers into thinking that they were Malays." 
soto $n$. [Malay, orig. Javanese Malay] A spicy chicken soup with noodles or rice cakes.

2001 New Straits Times 28 Nov. I'm a soto fan and the best soto is at a small shop by the seashore of Pasir Gudang, Johor.

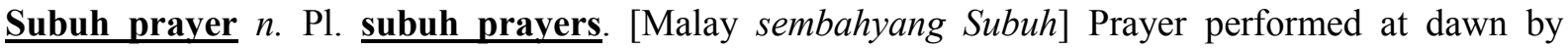
Muslims.

2001 New Straits Times 26 Aug. I leave my house just after Subuh prayers.

Sultan $n$. P1. -s. [Malay, orig. Arabic] 1 The sovereign of a Muslim country. 2 A sovereign of any of the nine former Federated and non-Federated Malay states. 3 The title of the sovereign of a Muslim country or the nine former Federated and non-Federated Malay states.

12001 The Star 4 Oct. The Sultan of Brunei was also conferred an honorary doctorate in Political Science by the International Islamic University (IIU) on Tuesday. 22001 New Straits Times 1 Oct. The winners received their prizes from the Sultan of Pahang at the closing ceremony .... 32001 The Star 2 Oct. Sultan Azlan Shah said although a conducive working environment and an effective administrative system were already in place a long time ago in the state, he hoped it could be enhanced from time to time.

surau $n$. Pl. same, -s. [Malay] A small mosque.

2001 New Straits Times 26 Aug. I don't believe in having kindergartens in suraus and houses.

syair $n$. [Malay, orig. Arabic] A poem comprising successive verses of four rhyming lines.

2001 New Straits Times 7 Sept. ... they were encouraged to express themselves "the Malaysian way" - sing a patriotic number accompanied by a skit, which could also include some poetry syair, gurindam, puisi, sajak or pantun - recitals.

syariah $n$. \& $a$. [Malay, orig. Arabic] A $n$. Islamic principles. B $a$. That which is based on Islamic principles.

A 2001 New Straits Times 18 Aug. Adat, in the Middle East, represents the unwritten customary laws and practices that have the force of social laws and the syariah. As long as the customs do not contradict the syariah, it is acceptable. B 2001 The Star 17 Nov. He said Syariah laws constituted three main areas - qisas (discretion by bereaved families to either pardon an accused or allow the process of law to punish him), hudud (Allah's law) and ta'zir (enforcement of punishment).

Syawal $n$. [Malay, orig. Arabic] The tenth month of the Islamic calendar. The first day of Syawal signifies the end of the fasting month of Ramadan and is celebrated by Muslims all over the world.

2001 New Straits Times 27 Oct. "We will buy as many coconuts as we can so that we will have enough stock for Ramadan and Syawal," he told reporters...

Tan Sri $n$. [Malay] The second highest honorary, non-royal, non-hereditary title granted by the Yang di-Pertuan Agong.

2001 The Star 8 Oct. Mentri Besar Tan Sri Isa Abdul Samad said he had advised developers to drop prices to enable them to sell their properties.

tapai $n$. [Malay] 1 Fermented glutinous rice or tapioca, usually eaten as a sweet. 2 Sweet rice wine.

2001 New Straits Times 20 Nov. Appetisers include dates, pisang emas, tapai, pickles, cencaluk and tempoyak.

Comb.: tapai pulut fermented glutinous rice; tapai ubi fermented tapioca.

teh tarik $n$. [Malay] Hot tea which is aerated and made frothy by pouring it back and forth from one mug to another.

2001 New Straits Times 1 Sept. The informal chats, over a glass of teh tarik and mee goreng, have proven to be an invaluable source of information.

tempe $n$. [Malay] Fermented soy bean cakes. 
2001 New Straits Times 19 Sept. The spread includes nasi minyak jawa timur, daging dendeng berlado, sotong Kalimantan, salad ayam jawa, rojak bandung, begedil tempe, mee goreng jawa, traditional desserts and complimentary teh or kopi tarik.

tempoyak $n$. [Malay] Fermented durian.

Comb.: gulai tempoyak tempoyak-flavoured gravy; sambal tempoyak condiment of chilli paste and tempoyak.

terawih prayer (tautology) $n . \mathrm{Pl}$. terawih pravers. [Malay sembahyang terawih, orig. Arabic] Evening prayer performed by the Muslims during the fasting month.

2001 The Star 5 Dec. ... the Prime Minister told reporters after breaking fast and performing terawih prayers at the residence of Gua Musang MP Tengku Razaleigh Hamzah, who is also a former finance minister.

Terengganu $n$. [Malay] A state situated on the east coast of Peninsular Malaysia.

2001 The Star 20 Oct. Two years ago, a Singaporean female diver also lost her life under unclear circumstances in Terengganu.

thanksgiving kenduri $n$. [Malay kenduri kesyukuran] A feast held to give thanks to Allah, usually when one has recovered from a serious illness or when one has achieved success in an endeavour.

2001 The Star 13 Dec. "Sometimes he delivers it in person and sometimes a police personnel would deliver the cheque," she said, adding that she hoped to organise a thanksgiving kenduri for the Ruler.

tidak apa $a$. [Malay, lit. "does not matter"] Lackadaisical or apathetic. Often used in a disparaging sense.

2001 New Straits Times 16 Nov. I think there are two types - the ones who don't care (about their looks) and the ones who really DO. The vain ones and the tidak apa types.

Comb.: tidak apa attitude [Malay sikap tidak apa] an indifferent attitude.

2001 The Star 21 Nov. All I can assume is that, as Telekom Malaysia is monopolising fixed line services, it is too rich to bother about another subscriber, hence its tidak apa attitude.

tudung $n$. [Malay] A headscarf worn by Muslim women.

2001 The Star 23 Aug. Dr Lo'Lo' said a recent photograph in the Sunday Star, which depicted a woman scuba diver wearing the tudung, showed that she held to the Islamic requirement for women to cover their hair.

ulam $n$. [Malay] A selection of raw leaves and vegetables, usually eaten with sambal.

2001 New Straits Times 26 Nov. Break fast with dates and whet your appetite with kerabu, ulam and sambal such as gado-gado, ulam raja, pegaga, kacang botol, sambal mangga and sambal belacan.

Comb.: nasi ulam rice mixed with herbs, grated coconut, salted fish, etc.

ulama $n$. Also ulamak. Pl. same, -s. [Malay, orig. Arabic] A man or a group of men with Islamic education and Islam-related professions.

2001 The Star 13 Nov. He said the main cause of weaknesses among the Muslims was the misunderstanding perpetrated by the ulama, who misinterpret the Quran according to their own personal and political agenda, causing many to reject knowledge and education except for those pertaining to the religion.

ulu $n$. [Malay ulu, hulu hinterland] A rural back-country or up-country area which is associated with a lack of worldliness. Often used in a disparaging sense.

2002 The Star 20 Jan. When former Secretary of State Warren Christopher finally sat down, I remembered thinking to myself: "Life is strange. Here am I, a two-bit hack and lawyer from the ulu addressing a guy presidential hopeful Al Gore enlisted in his desperate battle to seize the Oval office." 
umrah $n$. [Malay, orig. Arabic] A secondary Islamic pilgrimage to Mecca.

2001 New Straits Times 27 Sept. Abdullah said the special passport would enable the Saudi Government to differentiate between Malaysians in the kingdom to perform umrah and others who came for other reasons.

ustaz $n$. [Malay, orig. Arabic] 1 A male Islamic teacher. 2 Title of a male Islamic teacher (with an initial capital).

12001 New Straits Times 20 Aug. Even mosque officials and ustaz are seen on the golf course now. 22002 The Star 5 Dec. The other two party officials were Penang PAS deputy commissioner Khalid Man and Ustaz Othman Ibrahim from Kedah.

ustazah $n$. [Malay, orig. Arabic] 1 A female Islamic teacher. 2 Title of a female Islamic teacher (with an initial capital).

22001 The Star 30 Oct. ... Training Division assistant director Ustazah Norliah Sajuri, ....

wakil rakyat $n$. [Malay] A member of Parliament or State Legislative Assembly.

2001 New Straits Times 25 Oct. As the designation of the job implies, the wakil rakyat represents all the people in his constituency whether they voted for him or not.

wali $n$. [Malay, orig. Arabic] In Islam, the mediator for women seeking marriage.

2001 New Straits Times 19 Oct. Although Semelai people are not Muslims, they still practise the nikah ceremony where a kadi marries the couple and the wali functions as a witness.

wau $n$. [Malay, orig. Dutch wouw]. A large local kite, usually flown (by adults) after the rice harvesting season, between May and July.

Comb.: wau bulan wau with a crescent-shaped tail.

2001 New Straits Times 19 Sept. Although "wau bulan" is the most popular, they come in all shapes and sizes - hence in a variety of names. Some are called wau katak, wau kucing, wau ikan, wau puyuh and wau bayan.

wayang $n$. [Malay, orig. Javanese Malay] A local theatrical performance.

Comb.: wayang kulit shadow play, theatrical performance where shadow images are projected before a backlit screen; wayang peranakan theatrical performance where the characters speak the Peranakan language.

2001 The Star 2 Oct. A cultural theatre showcasing Chinese operas, wayang kulit and traditional music is more appropriate and so much more tasteful.

Yang di-Pertua Negeri $n$. Also Yang di-Pertua Negri. [Malay, lit. "Ruler of State"] 1 The title of the State Governors of the Malaysian states of Penang, Malacca, Sabah and Sarawak. 2 One of the four largely symbolic heads of state or Governors of Penang, Malacca, Sabah and Sarawak.

12001 New Straits Times 17 Sept. About 3,000 people thronged Padang Merdeka here today to watch a parade which was held to commemorate the 71st official birthday of Yang di-Pertua Negeri Tun Sakaran Dandai and Malaysia Day. 22001 The Star 2 Sept. Once dissolution is consented to by the Yang di-Pertua Negri, he said a writ could be issued within four days and the required minimum of seven clear days given for campaigning immediately followed by a day's polling during the two-week school holidays.

Yang di-Pertuan Agong $n$. [Malay, lit. "Supreme Ruler"] 1 The official title of the head of state of Malaysia. 2 The head of state of Malaysia: since Malaysia is a constitutional monarchy, the role of the Yang di-Pertuan Agong is largely ceremonial. The position is sometimes glossed as King in English.

12001 New Straits Times 24 Nov. Sultan Sharafuddin was proclaimed the ninth Sultan of Selangor On Thursday following the demise of the Yang di-Pertuan Agong Sultan Salahuddin Abdul Aziz Shah on Wednesday. 22001 New Straits Times 22 Nov. AS the nation mourns the 
passing of Sultan Salahuddin Abdul Aziz Shah al-Haj Ibni Almarhum Sultan Hisamuddin Alam Shah al-Haj, his subjects will always remember him as "the Ruler with the soul of the people". He was installed as the 11th Yang di-Pertuan Agong in 1999. The King, who celebrated his $75^{\text {th }}$ birthday in June, performed his duties outstandingly with dignity and honour.

Yang di-Pertuan Besar $n$. [Malay, lit. "Great Ruler"] 1 The official title of the ruler of the state of Negeri Sembilan, Malaysia. 2 The ruler of the state of Negeri Sembilan, Malaysia.

12001 The Star 15 Nov. When asked why none of the assemblymen had taken part in debating the budget, Isa said it was because all of them had participated in debating the opening speech by Yang Di-Pertuan Besar Tuanku Ja'afar Tuanku Abdul Rahman, which covered many aspects. 3 Nov. 22001 The Star As eldest son of the Yang di-Pertuan Besar of Negeri Sembilan, he wears a number of hats with ease and flair.

zapin $n$. [Malay] Malay folk dance and music with Islamic influence.

2001 New Straits Times 9 Oct. The dance infuses elements of zapin, silat and modern and traditional elements that are quick and funny.

zina $n$. [Malay, orig. Arabic] Illicit sexual intercourse, an offence under the Syariah law of Malaysia.

2001 New Straits Times 23 Sept. Zina (unlawful sexual intercourse): punishable by stoning to death. 